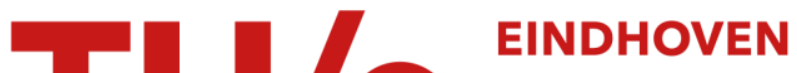

\section{Transition metal (Ti, Mo, Nb, W) nitride catalysts for lignin depolymerisation}

Citation for published version (APA):

Chen, L., Koranyi, T. I., \& Hensen, E. J. M. (2016). Transition metal (Ti, Mo, Nb, W) nitride catalysts for lignin depolymerisation. Chemical Communications, ChemComm, 52(60), 9375-9378 .

https://doi.org/10.1039/C6CC04702E

DOI:

10.1039/C6CC04702E

Document status and date:

Published: 27/06/2016

Document Version:

Accepted manuscript including changes made at the peer-review stage

Please check the document version of this publication:

- A submitted manuscript is the version of the article upon submission and before peer-review. There can be important differences between the submitted version and the official published version of record. People interested in the research are advised to contact the author for the final version of the publication, or visit the $\mathrm{DOI}$ to the publisher's website.

- The final author version and the galley proof are versions of the publication after peer review.

- The final published version features the final layout of the paper including the volume, issue and page numbers.

Link to publication

\section{General rights}

Copyright and moral rights for the publications made accessible in the public portal are retained by the authors and/or other copyright owners and it is a condition of accessing publications that users recognise and abide by the legal requirements associated with these rights.

- Users may download and print one copy of any publication from the public portal for the purpose of private study or research.

- You may not further distribute the material or use it for any profit-making activity or commercial gain

- You may freely distribute the URL identifying the publication in the public portal.

If the publication is distributed under the terms of Article 25fa of the Dutch Copyright Act, indicated by the "Taverne" license above, please follow below link for the End User Agreement:

www.tue.nl/taverne

Take down policy

If you believe that this document breaches copyright please contact us at:

openaccess@tue.nl

providing details and we will investigate your claim. 


\section{ChemComm}

\section{Transition metal ( $\mathrm{Ti}, \mathrm{Mo}, \mathrm{Nb}, \mathrm{W}$ ) nitride catalysts for lignin depolymerisation}

\begin{tabular}{|r|l|}
\hline Journal: & ChemComm \\
\hline Manuscript ID & CC-COM-06-2016-004702.R1 \\
\hline Article Type: & Communication \\
\hline Date Submitted by the Author: & n/a \\
\hline Complete List of Authors: & $\begin{array}{l}\text { Chen, Long; East China University of Science and Technology, } \\
\text { Korányi, Tamás; Tech. Univ. Eindhoven, } \\
\text { Hensen, Emiel; Eindhoven University of Techynology, Department of } \\
\text { Chemical Engineering and Chemistry }\end{array}$ \\
\hline
\end{tabular}

\section{SCHOLARONE ${ }^{m}$ \\ Manuscripts}




\section{Chemical Communications Guidelines for referees}

\section{ChemComm}

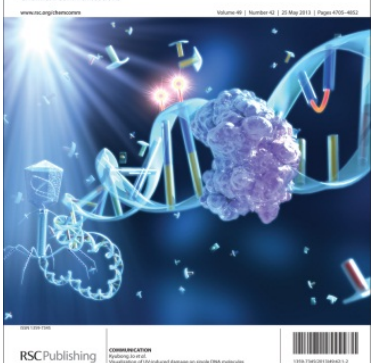

ChemComm is a forum for urgent high quality communications from across the chemical sciences.

Communications in ChemComm should be preliminary accounts of original and urgent work of significance to a general chemistry audience. The 2014 impact factor for ChemComm is $\mathbf{6 . 8 3}$.

Only work within the top $25 \%$ of the field in terms of quality and interest should be recommended for publication. Acceptance should only be recommended if the content is of such urgency and significant general interest that rapid publication will be advantageous to the progress of chemical research.

\section{Routine and incremental work - however competently researched and reported - should not be recommended for publication.}

\section{Articles which rely excessively on supplementary information should not be recommended for publication.}

Thank you very much for your assistance in evaluating this manuscript.

\section{General Guidance}

Referees have the responsibility to treat the manuscript as confidential. Please be aware of our Ethical Guidelines, which contain full information on the responsibilities of referees and authors, and our Refereeing Procedure and Policy.

\section{Supporting information and characterisation of new compounds}

Experimental information must be provided to enable other researchers to reproduce the work accurately. It is the responsibility of authors to provide fully convincing evidence for the homogeneity, purity and identity of all compounds they claim as new. This evidence is required to establish that the properties and constants reported are those of the compound with the new structure claimed.

Please assess the evidence presented in support of the claims made by the authors and comment on whether adequate supporting information has been provided to address the above. Further details on the requirements for characterisation criteria can be found here.

\section{When preparing your report, please:}

- comment on the originality, significance, impact and scientific reliability of the work;

- state clearly whether you would like to see the article accepted or rejected and give detailed comments (with references, as appropriate) that will both help the Editor to make a decision on the article and the authors to improve it;

- it is the expectation that only work with two strong endorsements will be accepted for publication.

\section{Please inform the Editor if:}

- there is a conflict of interest;

- there is a significant part of the work which you are not able to referee with confidence;

- the work, or a significant part of the work, has previously been published;

- you believe the work, or a significant part of the work, is currently submitted elsewhere;

- the work represents part of an unduly fragmented investigation. 


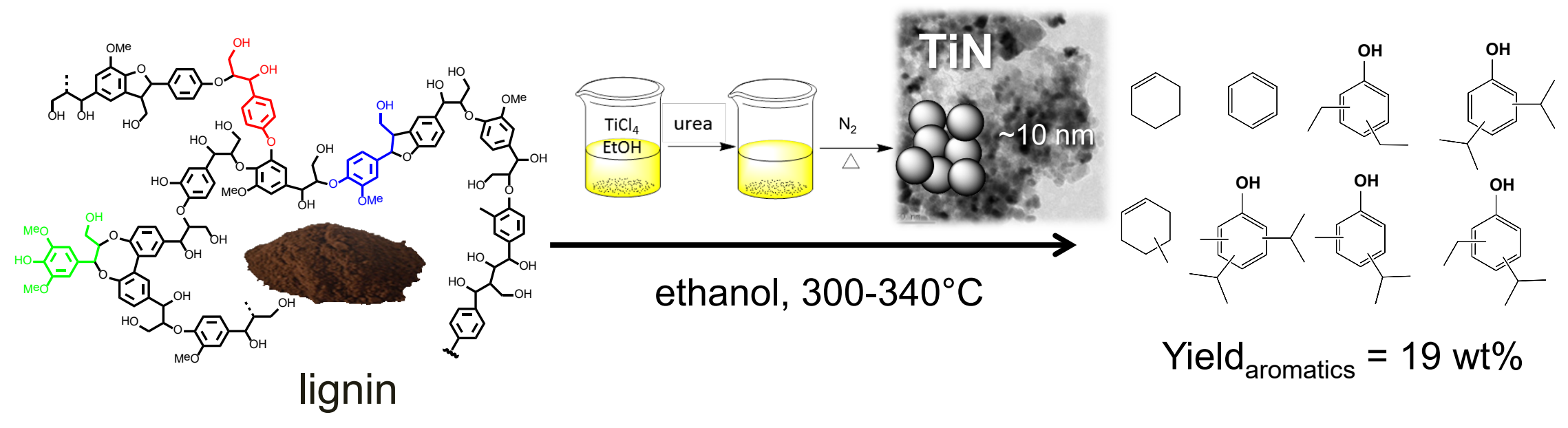




\title{
COMMUNICATION
}

Cite this: DOI: 10.1039/xoxxooooox

\section{Transition metal ( $\mathrm{Ti}, \mathrm{Mo}, \mathrm{Nb}, \mathrm{W})$ nitride catalysts for lignin depolymerisation}

\author{
Long Chen, Tamás I. Korányi, Emiel J.M. Hensen*
}

Received ooth January 2015,

Accepted ooth January 2015

DOI: $10.1039 /$ xoxxooooox

www.rsc.org/

Metal nitrides are promising catalysts for depolymerisation of lignin in supercritical ethanol; cheap and abundant titanium nitride affords an aromatic monomer yield of $19 \mathrm{wt} \%$ from soda lignin. The reaction mechanism is discussed on the basis of the products and a guaiacol model compound study.

The inevitable decrease in the supply of cheap petroleum resources, the increased energy demand in emerging economies and environmental concerns about climate change are main motivators for developing sustainable processes for production of fuels and chemicals. Lignocellulosic biomass is the only sustainable source of organic carbon. ${ }^{1}$ Interest in lignin upgrading has increased because the amount of waste lignin in biorefineries is expected to be substantial. $^{2}$ Lignin constitutes $15-30 \mathrm{wt} \%$ of lignocellulosic biomass with an energy content of up to $40 \%{ }^{3}$ Lignin is also the only renewable source of aromatics. ${ }^{4}$ Compared with upgrading of (hemi)cellulose, lignin valorisation is technically challenging because of its low reactivity and heterogeneity in terms of the chemical bonds between its constituents. Another aspect is the high reactivity of the low-molecular-weight fragments from lignin, which are usually rapidly recondensed, forming an even more refractory product than the parent lignin. ${ }^{2(a), 5}$ To date, various strategies for lignin valorisation have emerged, such as cracking, reduction and oxidation. $^{4 \mathrm{c}, 6}$ Oil yields are relatively low, and char and tar are common side-products. Usually, catalysts contain precious group metals (PGMs), which limits the viability of such processes for large-scale production of fuels and chemicals.

Transition metal nitrides have shown promise as active catalysts for hydrodesulfurization and hydrodeoxygenation reactions of fossil and biomass feedstock. ${ }^{7}$ Compared with metal sulphides commonly used in such operations, metal nitrides are appealing, because they have properties that place them between high performance ceramics and PGMs. ${ }^{8}$ They are resistant against corrosion, which is advantageous in large-scale lignin conversion processes that typically require harsh conditions. ${ }^{9}$ There are relatively few examples of the use of metal nitrides in lignin upgrading. Ma et al. ${ }^{10}$ demonstrated catalytic conversion of Kraft lignin in supercritical ethanol over $\mathrm{Mo}_{2} \mathrm{~N} / \mathrm{Al}_{2} \mathrm{O}_{3}$ catalyst without external hydrogen. Only few works have dealt with the use of TiN in this context. ${ }^{11} \mathrm{Ni}$ in combination with TiN shows promise in the hydrogenolysis of aryl ethers. ${ }^{11 a}$ Partial depolymerization of Kraft lignin with relatively low aromatic monomer yield $(<5 \mathrm{wt} \%)$ was achieved with a $\mathrm{Ni} / \mathrm{TiN}$ combination, in which $\mathrm{Ni}$ was partially doped into TiN. ${ }^{11 \mathrm{~b}}$ Herein, we show that TiN itself is a promising catalyst for depolymerisation of soda and organosolv lignin. In this work, we demonstrate that good monomer yield (19 wt\%) can be obtained using TiN in supercritical ethanol. The excellent performance of $\mathrm{TiN}$ in comparison to $\mathrm{TiO}_{2}$ and other metal nitrides is emphasized.

TiN nanoparticles were synthesized by the urea glass method (see the experimental section in ESI $\dagger$ ) followed by passivation in diluted oxygen. ${ }^{12}$ The XRD pattern in Figure Sla shows that pure TiN (JCPDS 87-0633) was obtained by this high-temperature approach. From XRD, we estimated an average size of $11 \mathrm{~nm}$ for the TiN crystals, consistent with TEM results (Figure S2, ESI $\dagger$ ). The BET surface area of TiN was about $107 \mathrm{~m}^{2} / \mathrm{g}$ (Figure S3, ESI $\dagger$ ), which was much higher than that of a commercial TiN sample $\left(3 \mathrm{~m}^{2} / \mathrm{g}\right.$, TEM image is shown in Figure S4). The Ti $2 p$ envelope of the XPS spectrum of TiN, which is shown in Figure S1b, evidences that TiN and Ti-oxynitride are present. ${ }^{13}$ The oxynitride surface species originate from the passivation step.

We first screened various Ti-based catalysts for the depolymerisation of soda lignin (GreenValue P1000, obtained by $\mathrm{NaOH}$ pulping of wheat straw) in ethanol at $300{ }^{\circ} \mathrm{C}$ (Table 1, entries 1-4). We employed an extensive work-up procedure to allow accurate quantification of monomers, THF-soluble lignin residue (with molecular weights close to or lower than the starting lignin), THFinsoluble lignin residue (high molecular weight products attached to the catalyst) and char (see ESI $\dagger$ ). Among these catalysts, the homemade TiN nanoparticles (Table 1, entry 4) showed the highest activity in terms of monomer yield (12 wt \%).

TiN made by the urea glass method is much more active in lignin depolymerization than the commercial TiN sample. The higher activity of the urea glass TiN sample is likely due to the much smaller particle size, ${ }^{14}$ yet also the deeper oxidation of the surface of the commercial TiN sample may have to do with this. In any case, $\mathrm{TiO}_{2}$ itself is a poor catalyst. ${ }^{11 \mathrm{~b}}$ Besides promising monomer yield, the urea glass TiN sample only produces $4 \mathrm{wt} \%$ char, much lower than the other catalysts and also than the blank reaction experiment. We speculate that lignin is thermally fragmented in supercritical ethanol, consistent with the notion that most of the $\beta-O-4$ ether linkages are cleaved between $200-400{ }^{\circ} \mathrm{C} .{ }^{15}$ The relatively high reaction temperature employed here is expected to facilitate the cleavage of less reactive linkages present in the lignin. 


\section{COMMUNICATION}

Table 1. Yields of monomers, lignin residues and char after of $\mathrm{P} 1000$ lignin in supercritical ethanol for various catalysts.

\begin{tabular}{|c|c|c|c|c|c|c|}
\hline Entry & Catalyst & $\begin{array}{l}\text { Temp. } \\
\left({ }^{\circ} \mathrm{C}\right)\end{array}$ & Lignin & $\begin{array}{c}\text { Monomer yield } \\
(w t \%)\end{array}$ & $\begin{array}{c}\text { THF-soluble } \\
\text { (wt\%) }\end{array}$ & $\begin{array}{l}\text { Char } \\
(w t \%)\end{array}$ \\
\hline 1 & Blank & 300 & P1000 & 1 & 30 & 44 \\
\hline 2 & $\mathrm{TiO}_{2}(\mathrm{P} 25)$ & 300 & P1000 & 6 & 42 & 26 \\
\hline 3 & TiN (Sigma) & 300 & P1000 & 1 & 39 & 22 \\
\hline 4 & TiN (urea glass) & 300 & P1000 & 12 & 61 & 4 \\
\hline 5 & Blank & 340 & P1000 & 1 & 36 & 51 \\
\hline 6 & $\mathrm{TiO}_{2}(\mathrm{P} 25)$ & 340 & P1000 & 9 & 41 & 35 \\
\hline 7 & TiN (Sigma) & 340 & P1000 & 2 & 39 & 39 \\
\hline 8 & TiN (urea glass) & 340 & P1000 & 19 & 51 & 11 \\
\hline 9 & $\mathrm{NbN}$ (urea glass) & 340 & P1000 & 17 & 61 & 12 \\
\hline 10 & $\mathrm{Mo}_{2} \mathrm{~N}$ (urea glass) & 340 & P1000 & 7 & 59 & 15 \\
\hline 11 & $\mathrm{~W}_{2} \mathrm{~N}$ (urea glass) & 340 & P1000 & 3 & 65 & 34 \\
\hline 12 & TiN (urea glass) & 340 & Organosolv - straw & 16 & 50 & 13 \\
\hline 13 & TiN (urea glass) & 340 & Organosolv - poplar & 15 & 47 & 15 \\
\hline 14 & TiN (urea glass) & 340 & Organosolv - spruce & 21 & 45 & 11 \\
\hline
\end{tabular}

To verify this, we depolymerized lignin at the higher temperature of $340{ }^{\circ} \mathrm{C}$ (Table 1, entries 5-8), which led to increased monomer yield for TiN (19 wt \%). At this stage, we also included several other metal nitrides $\left(\mathrm{NbN}, \mathrm{Mo}_{2} \mathrm{~N}\right.$ and $\left.\mathrm{W}_{2} \mathrm{~N}\right)$ prepared by the same urea glass method (see basic characterization in Figures S5-S8 in ESI $\dagger$ ) for comparison. The performance of $\mathrm{NbN}$ was comparable in terms of monomer and char yield, while Mo- and W-nitrides produced less monomers and more char. The lowest performance of $\mathrm{W}_{2} \mathrm{~N}$ is likely due to the low dispersion.

In attempting to understand the mechanism of the complex depolymerisation process catalysed by $\mathrm{TiN}$, we investigated the main reaction products in more detail. The monomer product distribution for the TiN catalyst at $300{ }^{\circ} \mathrm{C}$ and $340{ }^{\circ} \mathrm{C}$ is shown in Figure 1. The products are categorized in three classes, namely hydrogenated cyclics, oxygen-free aromatics and oxygen-containing aromatics. The presence of hydrogenated cyclic products can be attributed to the slightly metallic character of TiN, which facilitates hydrogen transfer reactions of the solvent. ${ }^{16}$ The yield of hydrogenated cyclics (mostly cyclohexenes) is relatively low, yet increases with temperature. Strikingly, a significant amount of alkylated aromatic products was obtained in these lignin depolymerisation reactions. The extent of alkylation was higher at $340{ }^{\circ} \mathrm{C}$, pointing to the importance of alkylation in obtaining good monomer yield. TiN is an active catalyst for aromatics alkylation with alcohols. ${ }^{17}$ The relation between alkylation and monomer yield in lignin depolymerisation is in keeping with results of Huang et al., ${ }^{18}$ who found that alkylation of reactive phenolic intermediates suppresses their recondensation into heavy products. Although not all alkyl side-chains in the aromatic monomers could be identified, we authenticated 2,6-di-t-butylphenol as one of the products. Compared with the work of Huang et al. ${ }^{18}$ employing a mixed $\mathrm{Cu}$ Mg-Al-oxide catalyst, more $t$-butylation was observed, which is due to the partial conversion of ethanol to $t$-butanol with TiN. $i$ Propylation of aromatics derives from $i$-propanol, which is observed as the product of condensation of methanol, obtained by demethoxylation of lignin, and ethanol. The alkylation degree of the few aromatic monomers obtained with $\mathrm{TiO}_{2}$ and the commercial TiN sample was much lower.
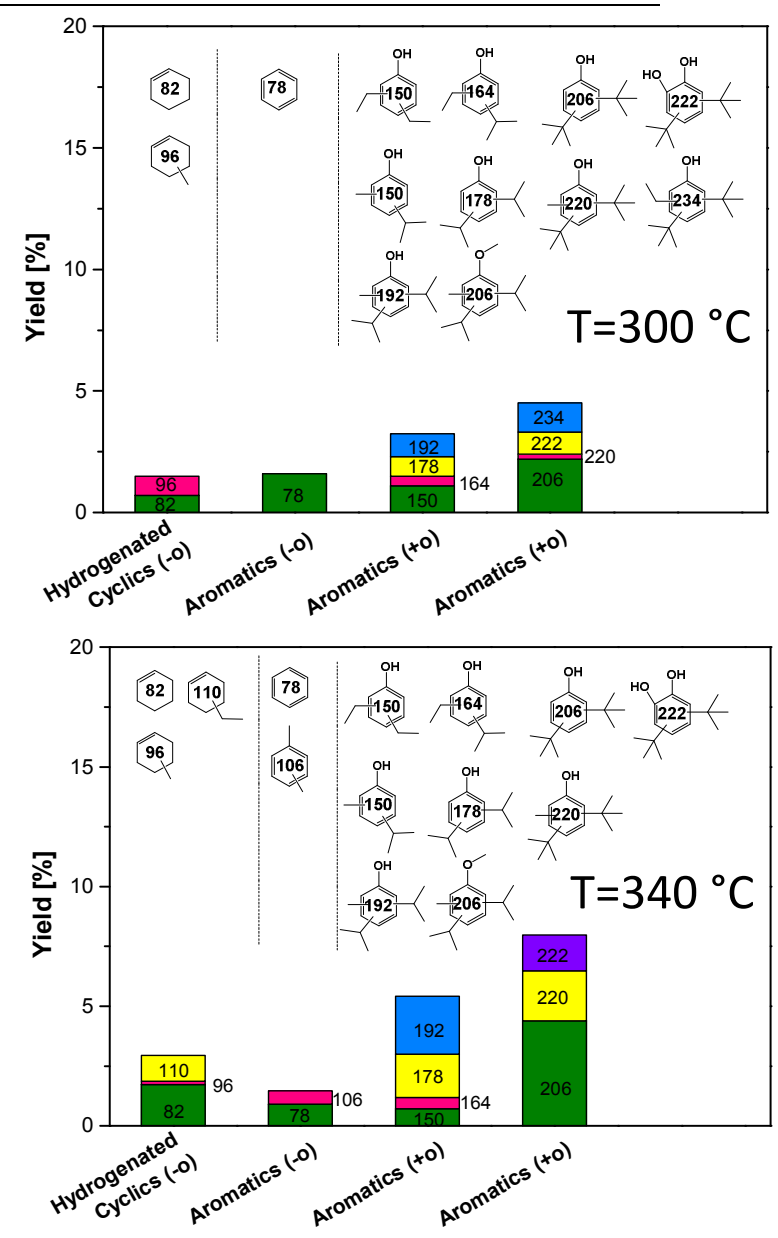

Figure 1. Distribution of monomeric products from lignin depolymerisation using TiN at $300{ }^{\circ} \mathrm{C}$ (top) and $340{ }^{\circ} \mathrm{C}$ (bottom), entries 4 and 8 in Table 1. 
In order to better understand the changes occurring during lignin depolymerisation, we also investigated the THF-soluble lignin residue in more detail. GPC analysis (Figure S9, ESI $\dagger$ ) demonstrates that the molecular weight of the lignin residue is lower than that of the starting lignin. Comparison of ${ }^{13} \mathrm{C}-{ }^{1} \mathrm{H}$ HSQC NMR spectra (Figure S10, ESI $\dagger$ ) of the parent lignin and this residue showed the appearance of cross-peaks of alkyl groups bound to aromatic rings. Thus, alkylation by alcohols catalysed by TiN protects aromatic monomers from being recondensed, which explains the high monomer and lower char yield. This conclusion is further underpinned by the low monomer and high char yield in the absence of catalysts that can catalyse alkylation. It is also important to stress that only very few gaseous hydrocarbon products were obtained in the experiments with TiN, which constrasts the more prominent gas make by ethanol reforming in the presence of metallic catalysts. ${ }^{18}$ Detailed product distributions for lignin depolymerisation using $\mathrm{NbN}, \mathrm{Mo}_{2} \mathrm{~N}$ and $\mathrm{W}_{2} \mathrm{~N}$ catalysts are given in the ESI $\uparrow$ (Figure S11). From this, it can be concluded that $\mathrm{NbN}$ catalyses similar chemistry as TiN, which likely is due to the Lewis acidity of the exposed metal centers. $\mathrm{NbN}$ is less effective than TiN in oxygen removal, leading to high yield of oxygenated aromatics. On the other hand, $\mathrm{Mo}_{2} \mathrm{~N}$ and $\mathrm{W}_{2} \mathrm{~N}$ produce much more oxygen-free aromatics consistent with the notion that these nitrides, just like their carbidic and sulphidic counterparts, are good catalysts for hydrodeoxygenation of oxygenated aromatics. ${ }^{19}$ The lower monomer yields obtained with $\mathrm{Mo}_{2} \mathrm{~N}$ and $\mathrm{W}_{2} \mathrm{~N}$ appear to be correlated with their lower alkylation activity. Relatively speaking, these catalysts produce more aromatics than $\mathrm{TiN}$ and $\mathrm{NbN}$.

To assess the utility of the TiN catalyst in lignin depolymerisation, we evaluated its performance in depolymerising three different types of organosolv lignin originating from wheat straw and poplar and spruce wood (Table 1, entries 9-11). In all of these cases, the depolymerisation process proceeded efficiently, resulting in comparable monomer yield with relatively small amounts of char. The lower monomer yield obtained from wheat straw is likely due to the higher fraction of C-C type intralinkages in this type of lignin, which relates to its relatively high $\mathrm{H}$ unit content. The monomer products distribution obtained from these different lignin sources were similar with the one of P1000 lignin (Figure S12, ESI $\dagger$ ). These results underpin the high efficiency and versatility of high surface area TiN prepared by the urea glass method for lignin depolymerisation.

To gain further insight into the mechanism of lignin depolymerisation in the TiN-ethanol system, we determined by GCMS the products obtained in the conversion of guaiacol as a model compound. The conversion of guaiacol is nearly complete and the range of monomeric products in the chromatogram in Figure highlights the high rates of demethoxylation and alkylation. The amount of oligomerization is limited, showing the effectiveness of alkylation. ${ }^{20}$ Compared with lignin experiments, less $t$-butylation is observed, which is likely due to the larger amount of $i$-propanol formed due to condensation of methanol (from guaiacol demethoxylation) with ethanol. Another difference is that no ring hydrogenation is observed in the aromatic oxygenates obtained from guaiacol. This result is in keeping with the result that only aromatic rings of completely deoxygenated compounds are hydrogenated in the lignin conversion experiments. A tentative explanation is that the coordination of oxygenated aromatics is via the phenolic OH groups, while compounds like benzene will coordinate via their $\pi$-system to the surface.

In summary, transition metal nitrides and especially nanoparticulate TiN are promising for the partial depolymerisation of lignin. Good aromatic monomer yields at relatively low char formation rate can be obtained in supercritical ethanol. Key to the promising monomer yield is aromatic ring alkylation. While $\mathrm{NbN}$ catalyses similar chemistry $\mathrm{Mo}_{2} \mathrm{~N}$ and $\mathrm{W}_{2} \mathrm{~N}$ show much lower performance in terms of monomer yield. The alkylation degree of these monomers is lower, yet more deoxygenated and hydrogenated products are observed. TiN can be used to partially depolymerise soda and organosolv lignin with promising monomer yield.

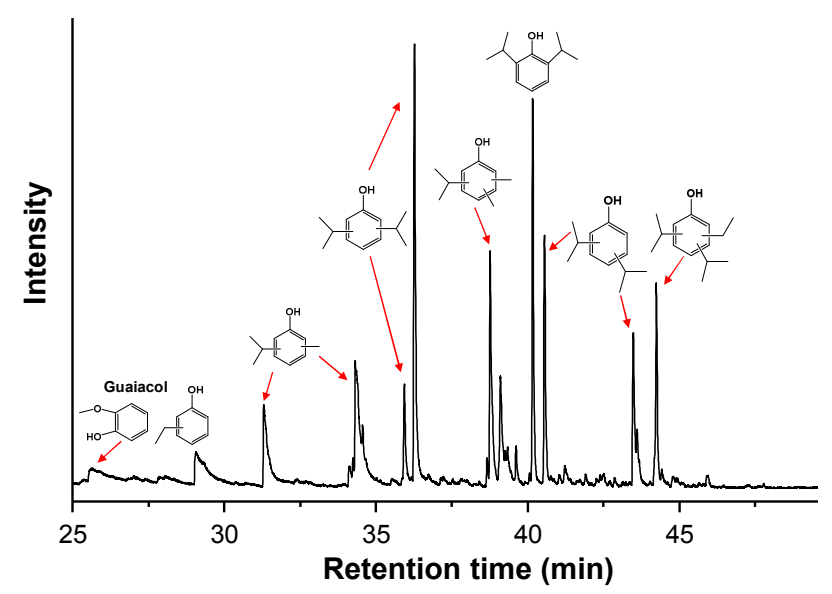

Figure 2. GC-MS chromatogram of guaiacol conversion in supercritical ethanol at $300^{\circ} \mathrm{C}$ catalysed by urea glass prepared TiN.

\section{Acknowledgements}

The authors gratefully acknowledge the support of CatchBio, the Smart Mix Program of the Netherlands Ministry of Economic Affairs and the Netherlands Ministry of Education, Culture and Science.

\section{Notes and references}

Laboratory of Inorganic Materials Chemistry, Schuit Institute of Catalysis, Department of Chemical Engineering and Chemistry, Eindhoven University of Technology, P.O. Box 513, 5600 MB Eindhoven, The Netherlands. E-mail: e.j.m.hensen@tue.nl

† Electronic Supplementary Information (ESI $\dagger$ ) available: Experiments and catalyst characterization details, products distributions, lignin residue characterisation results. See DOI:10.1039/b000000x/

1. a) G. W. Huber, S. Iborra, A. Corma, Chem. Rev. 2006, 106, 4044-4098; b) A. J. Ragauskas, C. K. Williams, B. H. Davison, G. Britovsek, J. Cairney, C. A. Eckert, W. J Frederick Jr., J. P. Hallett, D. J. Leak, C. L. Liotta, J. R. Mielenz, R. Murphy, R. Templer, T. Tschaplinski, Science 2006, 27, 484-489.

2. a) A. J. Ragauskas, G. T. Beckham, M. J. Biddy, R. Chandra, F. Chen, M. F. Davis, B. H. Davison, R. A. Dixon, P. Gilna, M. Keller, P. Langan, A. K. Naskar, J. N. Saddler, T. J. Tschaplinski, G. A. Tuskan, C. E. Wyman, Science 2014, 344, 1246843; b) J. G. Lingera, D. R. Vardona, M. T. Guarnieri, E. M. Karp, G. B. Hunsinger, M. Ann Franden, C. W. Johnson, G. Chupkad, T. J. Strathmannc, P. T. Pienkosa, G. T. Beckham, Proc. Natl. Acad. Sci. 2014, 111, 12013-12018.

3. a) M. Stöcker, Angew. Chem. Int. Ed. 2008, 47, 9200-9211; b) J. R. Regalbuto, Science 2009, 325, 822-824.

4. a) C. O. Tuck, E. Pérez, I. T. Horváth, R. A. Sheldon, M. Poliakoff, Science 2012, 337, 695-699; b) S. R. Collinson, W. Thielemans, Coord. Chem. Rev. 2010, 254, 1854-1870; c) J. Zakzeski, P. C. A. Bruijnincx, A. L. Jongerius, B. M. Weckhuysen, Chem. Rev. 2010, 110, 3552-3599.

5. J. Y. He, C. Zhao, D. H. Mei, J. A. Lercher, J. Catal. 2014, 309, 280290.

6. a) Y. Zheng, D. Y. Chen, X. F. Zhu, J. Anal. Appl. Pyrol. 2013, 104, 514520 ; b) J. G. Zhang, J. Teo, X. Chen, H. Asakura, T. Tanaka, K. 
Teramura, N. Yan, ACS Catal. 2014, 4, 1574-1583; c) A. R. Gonçalves, P. Benar, Bioresource Technol. 2001, 79, 103-111.

7. a) I. T. Ghampson, C. Sepúlved, R. Garcia, L. R. Radovi, J. L. García Fierro, W. J. De Sisto, N. Escalona, Appl. Catal. A: Gen. 2012, 439, 111124; b) B. Diaz, S. J. Sawhill, D. H. Bale, R. Main, D. C. Phillips, S. Korlann, R. Self, M. E. Bussell, Catal. Today, 2003, 86,191-206.

8. a) R. B. Levy, M. Boudart, Science 1973, 181, 547-549; b) H. H. Hwu, J. G. Chen, Chem. Rev. 2005, 105, 185-212.

9. M. Marlo, V. Milman, Phys. Rev. B 2000, 62, 2899-2907.

10. X. Ma, R. Ma, W. Hao, M. Chen, F. Yan, K. Cui, Y. Tian, Y. Li, ACS Catal. 2015, 5, 4803-4813.

11. a) V. Molinari, C. Giordano, M. Antonietti, D. Esposito, J. Am. Chem. Soc. 2014, 136, 1758-1761; b) V. Molinari, G. Clavel, M. Graglia, M. Antonietti, D. Esposito, ACS Catal. 2016, 6, 1663-1670.

12. C. Giordano, C. Erpen, W. T. Yao, B. Milke, M. Antonietti, Chem. Mater., 2009, 21, 5136-5144

13. a) B. Yoo, K. J. Kim, Y. H. Kim, K. Kim, M. J. Ko, W. M. Kim, N. G. Park, J. Mater. Chem. 2011, 21, 3077-3084; b) X. Y. Liu , Y. H. Zhang, T. Wu, J. G. Huang, Chem. Commun. 2012, 48, 9992-9994.

14. a) S. Kaskel, K. Schlichte, G. Chaplais and M. Khanna, J . Mater. Chem. 2003, 13, 1496-1499; b) R. A. Janes, M. Aldissi and R. B. Kaner, Chem. Mater. 2003, 15, 4431-4435.

15. a) Q. Song, F. Wang, J. Y. Cai, Y. H. Wang, J. J. Zhang, W. Q. Yu, J. Xu, Energy Environ. Sci. 2013, 6, 994-1007; b) P. Ferrini, R. Rinaldi, Angew. Chem. Int. Ed. 2014, 53, 8634-8639. c) E. Dorrestijn, L. J. J. Laarhoven, I. W. C. E. Arends, P. Mulder, J. Anal. Appl. Pyrolysis 2000, 54, 153-192.

16. S. Kaskel, K. Schlichte, T. Kratzke, J. Mol. Catal. A: Chem. 2004, 208, 291-298.

17. a) W. T. Yao, P. Makowski, C. Giordano, F. Goettmann, Chem. Eur. J. 2009, 15, 11999-12004; b) A. Fischer, P. Makowski, J. Müller, M. Antonietti, A. Thomas, F. Goettmann, ChemSusChem 2008, 1, 444-449.

18. a) X. M. Huang, T. I. Korányi, M. D. Boot, E. J. M. Hensen, ChemSusChem, 2014, 7, 2276-2288; b) X. M. Huang, T. I. Korányi, M. D. Boot, E. J. M. Hensen, Green Chem. 2015, 17, 4941-4950; c) X. M. Huang, C. Atay, T. I. Korányi, M. D. Boot, E. J. M. Hensen, ACS Catal. $2015, \mathbf{5}, 7359-7370$.

19. C. Sepúlveda, K. Leiva, R. García, L. R. Radovic, I. T. Ghampson, W. J. De Sisto, J. L. García Fierro, N. Escalon, Catal. Today, 2011, 172, 232239.

20. a) A. Brandt, J. Grasvik, J. P. Hallett, T. Welton, Green Chem., 2013, 15, 550-583; b) A. Brandt, L. Chen, B. E. van Dongen, T. Welton, J. P. Hallett, Green Chem., 2015,17, 5019-5034; c) W. Boerjan, J. Ralph, M. Baucher, Annu. Rev. Plant Biol., 2003, 54, 519-546. 


\title{
Electronic Supplementary Information (ESI)
}

\section{Transition metal ( $\mathrm{Ti}, \mathrm{Mo}, \mathrm{Nb}, \mathrm{W}$ ) nitride catalysts for lignin depolymerisation

\author{
Long Chen, Tamás I. Korányi, Emiel J.M. Hensen*
} \\ Laboratory of Inorganic Materials Chemistry, Schuit Institute of Catalysis, Department of Chemical Engineering and Chemistry, Eindhoven University of Technology, P.O. Box 513, 5600 MB Eindhoven, The Netherlands. \\ E-mail:e.j.m.hensen@tue.nl}

\section{Experimental section}

\begin{abstract}
Materials
Titanium tetrachloride, molybdenum pentachloride, niobium pentachloride, tungsten tetrachloride, urea, titanium nitride were purchased from Sigma Aldrich. Titanium dioxide P25 was purchased from Degussa. Protobind 1000 alkali lignin (sulfur-free lignin with less than $4 \mathrm{wt} \%$ carbohydrate and less than $2 \mathrm{wt} \%$ ash) was purchased from Greenvalue. Three types of organosolv lignins were supplied by Energy research center of the Netherlands. All chemicals were used without further purification.
\end{abstract}

\section{Catalyst preparation}

A certain amount of metal chloride was added dropwise to ethanol, until a yellowish solution was observed. Urea was then added slowly to the solution under vigorous stirring for $1 \mathrm{~h}$. The molar ratio of titanium tetrachloride, molybdenum pentachloride, niobium pentachloride and tungsten tetrachloride to urea were 5, 3, 1 and 1, respectively. After this, the solvent was firstly evaporated in nitrogen, followed by drying in an oven at $80{ }^{\circ} \mathrm{C}$ overnight to form a gel. The gel was heated under nitrogen flow (heating rate of $2{ }^{\circ} \mathrm{C} / \mathrm{min}$ ) up to $750{ }^{\circ} \mathrm{C}$ holding the final temperature $\left(750{ }^{\circ} \mathrm{C}\right)$ for 3 hours. The high-surface-area TiN proved to be very pyrophoric. Therefore, the freshly synthesized material was passivated in a flowing $1 \% \mathrm{O}_{2} / \mathrm{He}$ for $12 \mathrm{~h}$ at room temperature.

\section{Catalyst characterization}

Transmission electron micrographs (TEM) were recorded on a FEI Tecnai 20 electron microscope, operated $200 \mathrm{kV}$ and equipped with a LaB6 filament. X-ray diffraction (XRD) measurements were performed on a Bruker D4 Endeavor Diffractometer using $\mathrm{Cu} \mathrm{K} \alpha$-radiation. $\mathrm{N}_{2}$ adsorption measurements were carried out Tristar 3000 automated gas adsorption system. Brunauer-Emmett-Teller (BET) method was used to determine the surface area. Prior to analysis, the samples were degassed at $100{ }^{\circ} \mathrm{C}$ under vacuum overnight. X-ray Photoelectron Spectroscopy (XPS) was done on a Kratos AXIS Ultra spectrometer, equipped with a monochromatic Al Ka X-ray source and a delay-line detector (DLD). Spectra were obtained using an aluminum anode $(\mathrm{Al} \mathrm{K \alpha}=1486.6 \mathrm{eV})$ operating at $150 \mathrm{~W}$, with survey scans at constant pass energy of $160 \mathrm{eV}$ and region scans at a constant pass energy of $40 \mathrm{eV}$. The background pressure was $2 \times 10^{-9}$ mbar. XP spectra were fitted with the CASAXPS software. Binding energies (BE) were calibrated using the carbon contamination present $(\mathrm{C} 1 \mathrm{~s}=284.6 \mathrm{eV})$. 


\section{Lignin depolymerization and guaiacol conversion}

$50 \mathrm{~mL}$ AmAr stirred high-pressure autoclaves were used. Typically, the autoclave was charged with a suspension of $200 \mathrm{mg}$ catalyst and $400 \mathrm{mg}$ lignin or guaiacol in $20 \mathrm{~mL}$ solvent. An amount of $10 \mu \mathrm{L} \mathrm{n}$-dodecane was added as the internal standard. The reactor was sealed and purged with nitrogen several times to remove oxygen. After leak testing, the pressure was set to 10 bar and the reaction mixture was heated to the desired reaction temperature under continuous stirring at $500 \mathrm{rpm}$ within $1 \mathrm{~h}$. After the reaction, the reactor was rapidly quenched to room temperature in a water bath. A work-up procedure for lignin systems as shown in Scheme S1 was developed. Firstly, $1 \mathrm{~mL}$ post-mixture was taken and filtered using $0.45 \mu \mathrm{m}$ syringe filter, then analyzed by the GC-MS. The remaining mixture were collected combining with the solution from washing the autoclave with ethanol. The combined mixture was then filtered, forming two fractions which were solid phase and liquid phase. The solid part was then washed using THF. The liquid part was first acidified with diluted $\mathrm{HCl}$ solution and then subjected to deionized water to precipitate unconverted lignin and high molecular-weight lignin fragments.

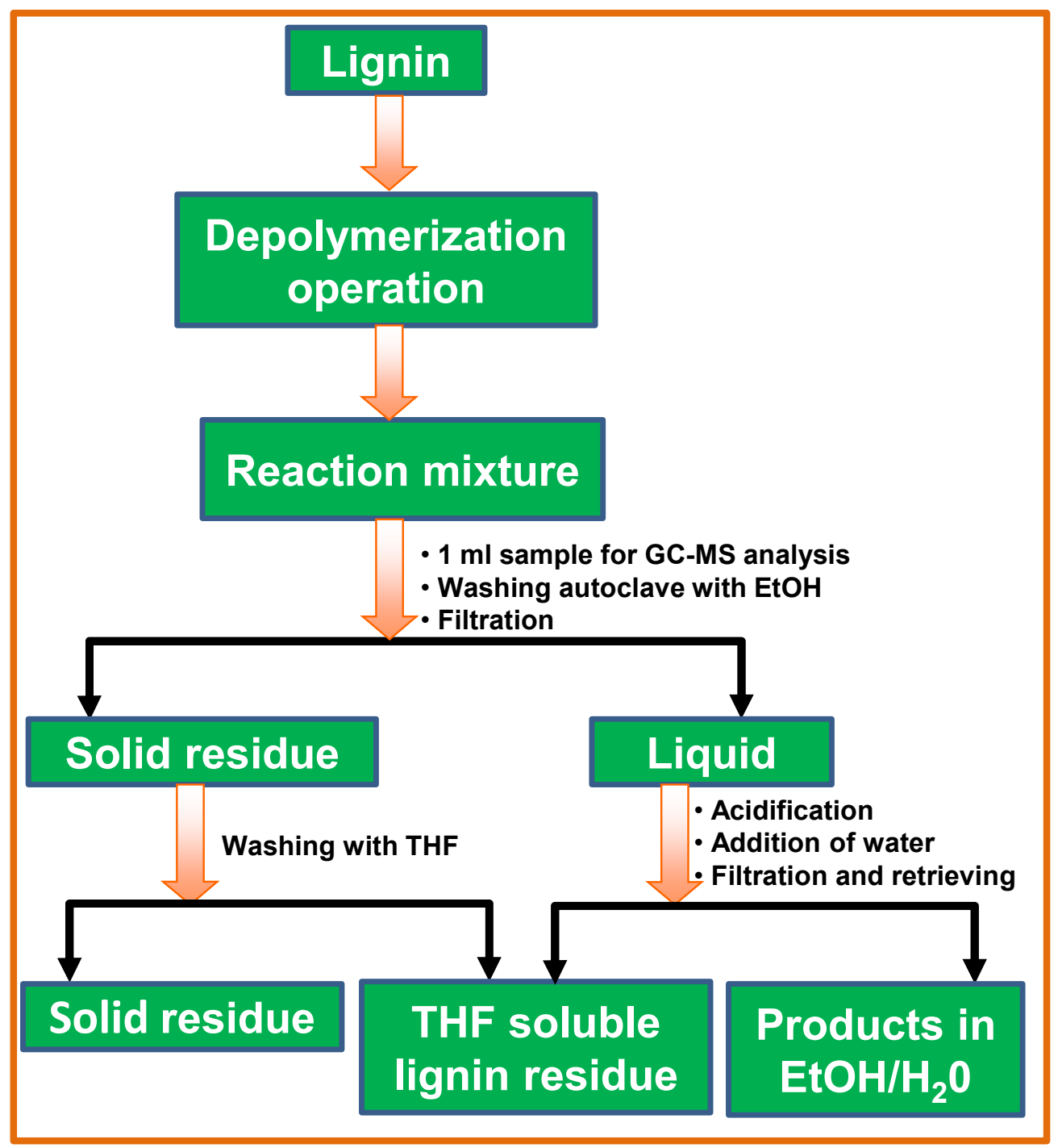

Scheme S1. Schematic diagram of the work up procedure. 


\section{${ }^{1} \mathrm{H}-{ }^{13} \mathrm{C}$ HSQC NMR analysis of lignin}

All NMR spectra were recorded using a Varian $500 \mathrm{MHz}$ spectrometer. Approximately $70 \mathrm{mg}$ of lignin residue (100 mg for P1000) was dissolved in $0.7 \mathrm{~mL}$ dimethylsulfoxide-d6 ([D6] DMSO). ${ }^{1} \mathrm{H}^{-13} \mathrm{C}$ HSQC NMR spectra were obtained using the Crisis gc2HSQC program. The spectral widths were $5000 \mathrm{~Hz}$ and $20000 \mathrm{~Hz}$ for the ${ }^{1} \mathrm{H}$ - and ${ }^{13} \mathrm{C}$-dimensions, respectively. Normally, the number of scans was 16 , and 256 time increments were always recorded in the ${ }^{13} \mathrm{C}$ dimension. Data processing was performed using the MestReNova software.

\section{Gel permeation chromatography (GPC)}

GPC analyses were performed by using a SHIMADZU apparatus equipped with two columns connected in series (Mixed-C and Mixed-D, polymer Laboratories) and a UV/Vis detector at $254 \mathrm{~nm}$. The column was calibrated with polystyrene standards. Analyses were carried out at $25^{\circ} \mathrm{C}$ using THF as eluent with a flow rate of $1 \mathrm{~mL} \mathrm{~min}{ }^{-1}$. Samples were dissolved with the concentration of $2 \mathrm{mg} \mathrm{mL}^{-1}$ and filtered using a $0.45 \mathrm{~mm}$ filter membrane prior to injection. 


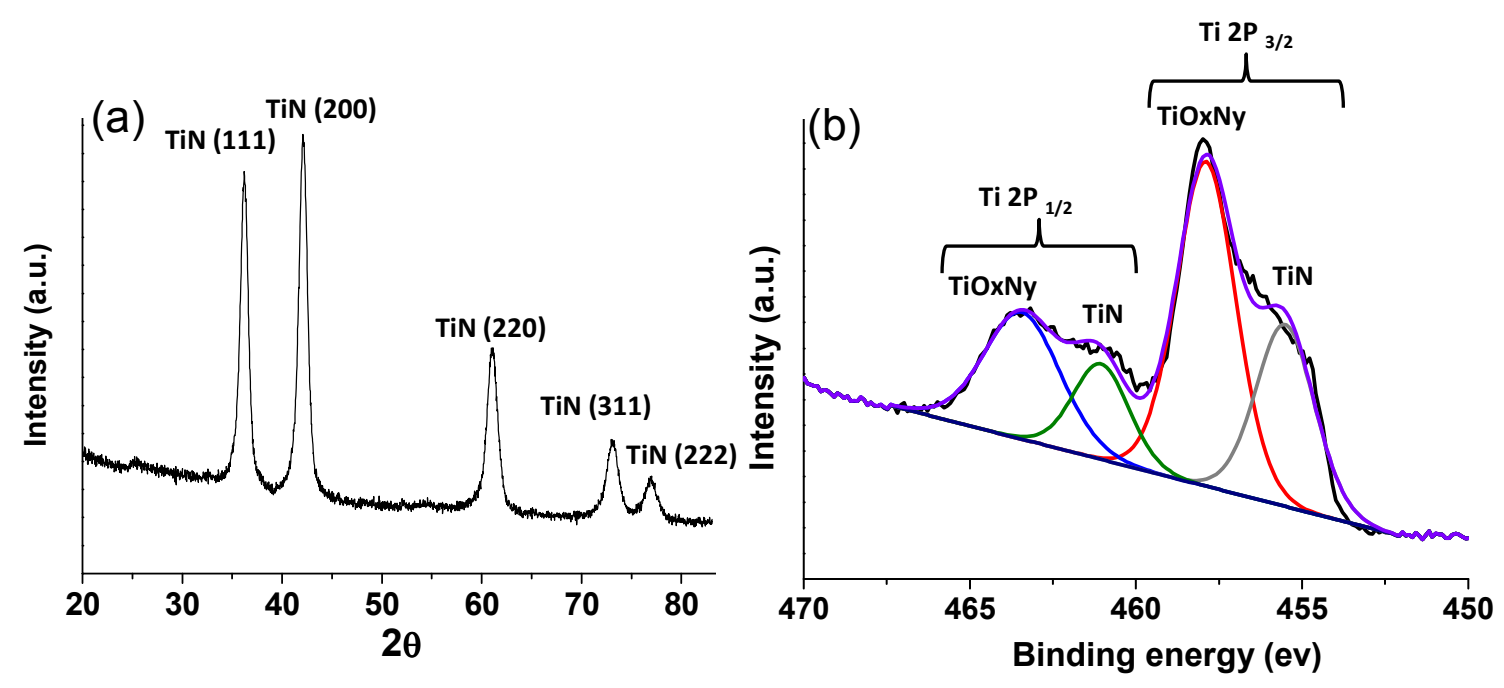

Figure S1. (a) XRD pattern and (b) Ti 2p region of the X-ray photoelectron spectrum of TiN prepared by the urea glass method.

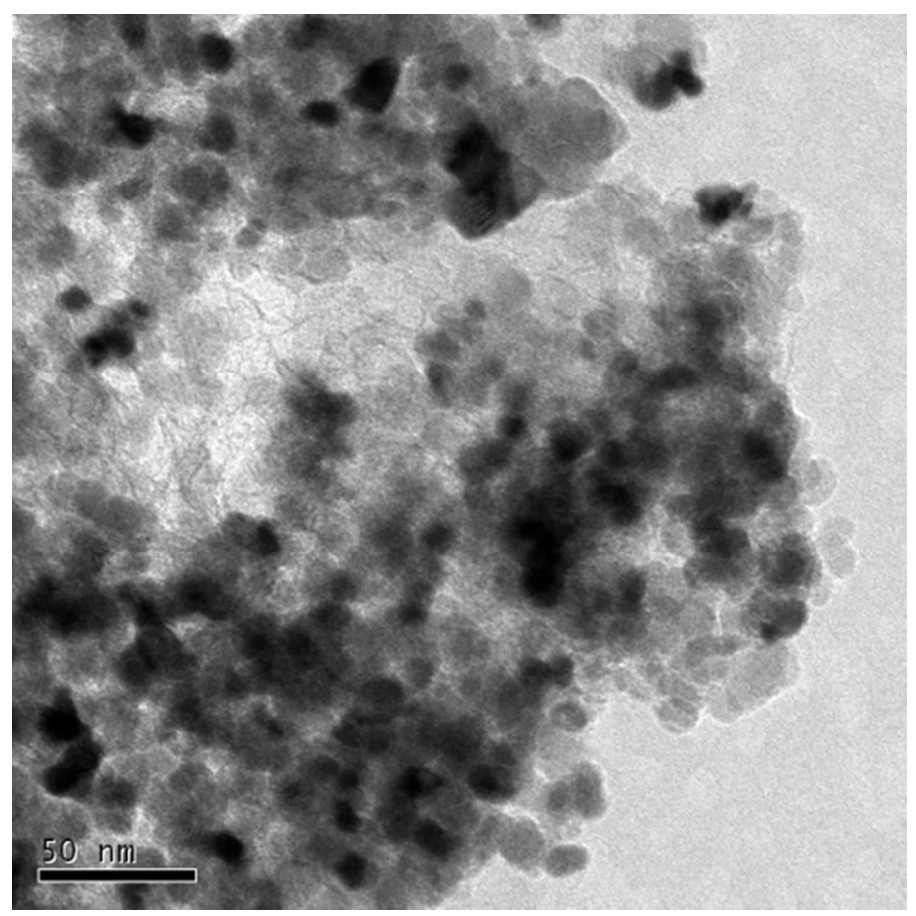

Figure S2. TEM image of TiN (urea glass). 


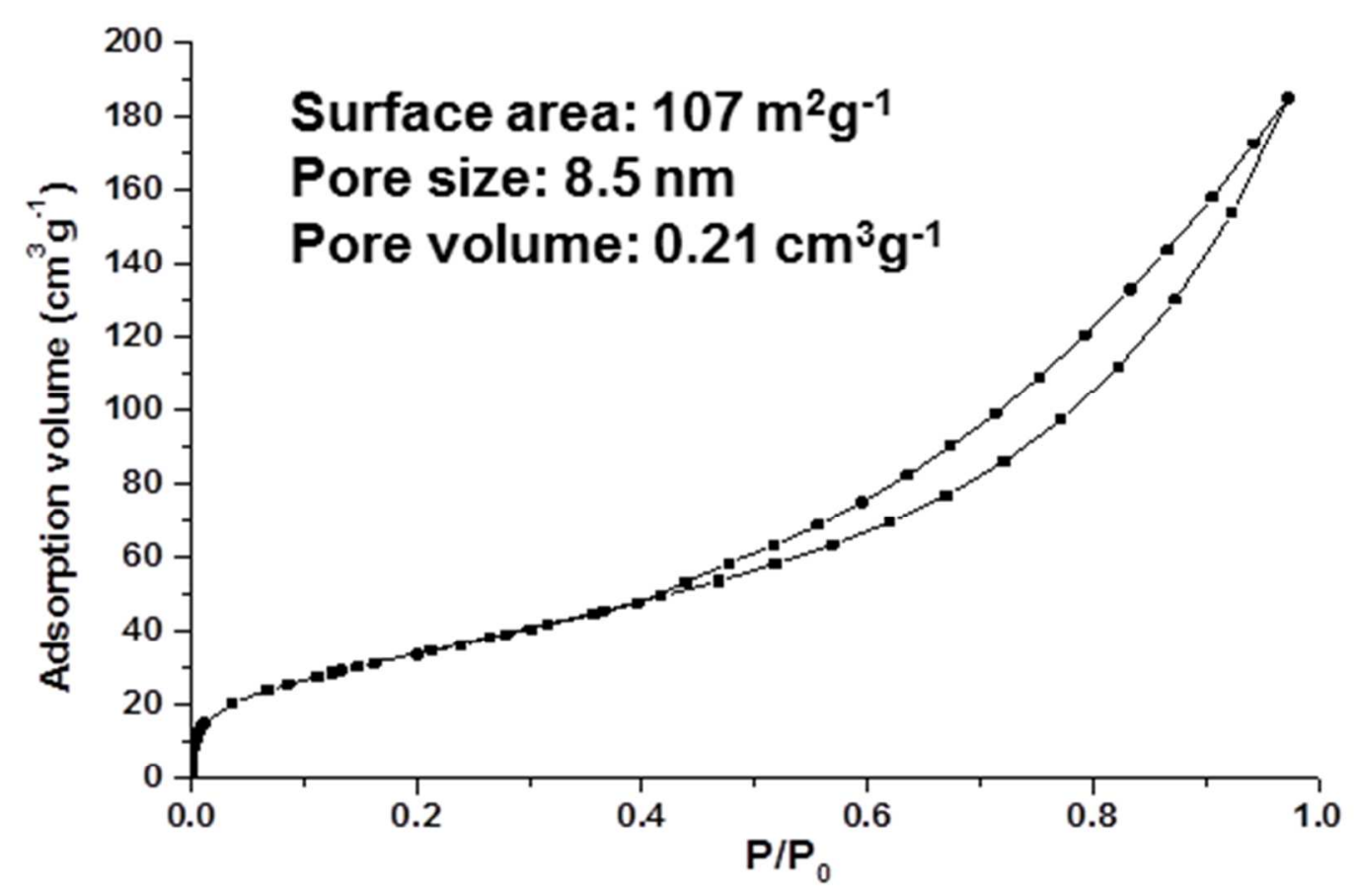

Figure S3. $\mathrm{N}_{2}$-adsorption/desorption isotherm of TiN (urea glass).

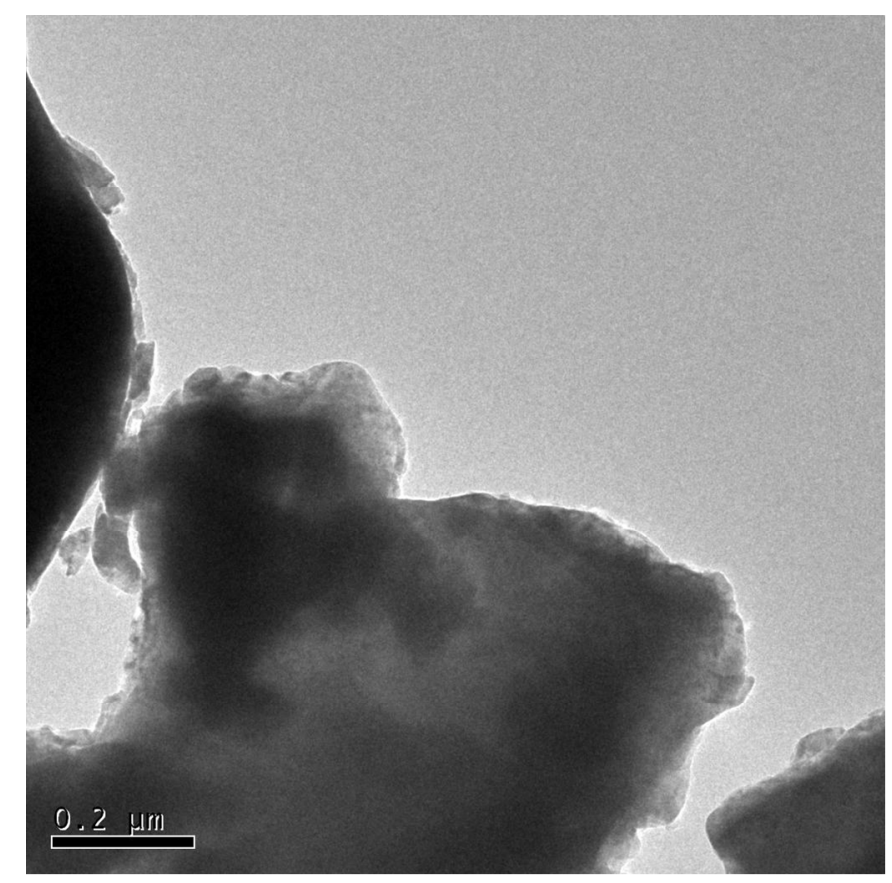

Figure S4. TEM of commercial TiN (Sigma). 


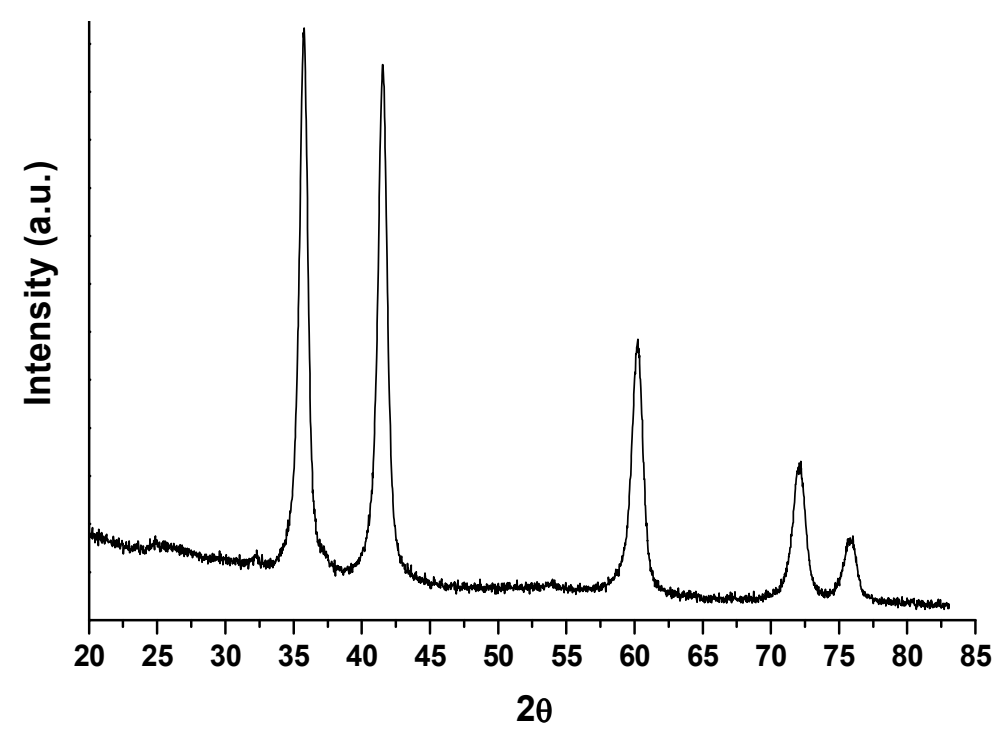

Figure S5. XRD pattern of $\mathrm{NbN}$.

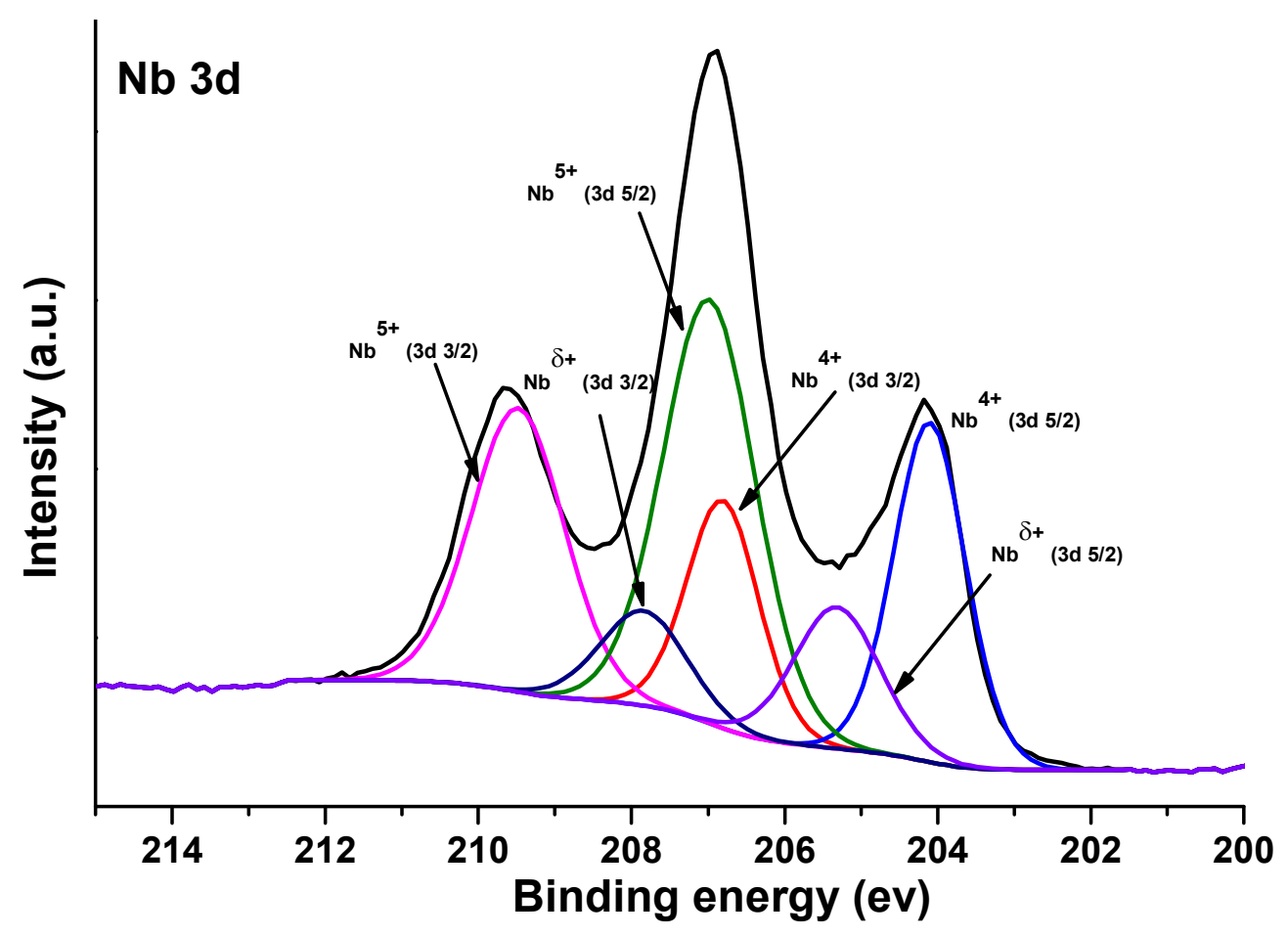

Figure S6. XPS spectrum of $\mathrm{Nb} 3 \mathrm{~d}$ region of $\mathrm{NbN}$. 


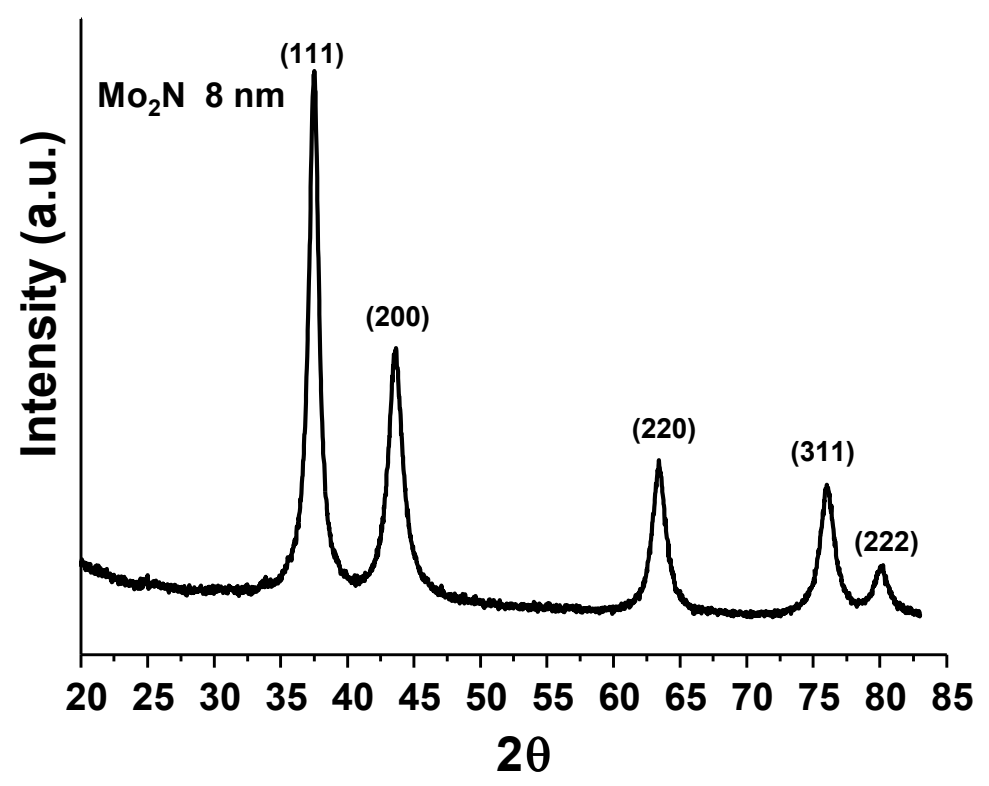

Figure S7. XRD pattern of $\mathrm{Mo}_{2} \mathrm{~N}$.

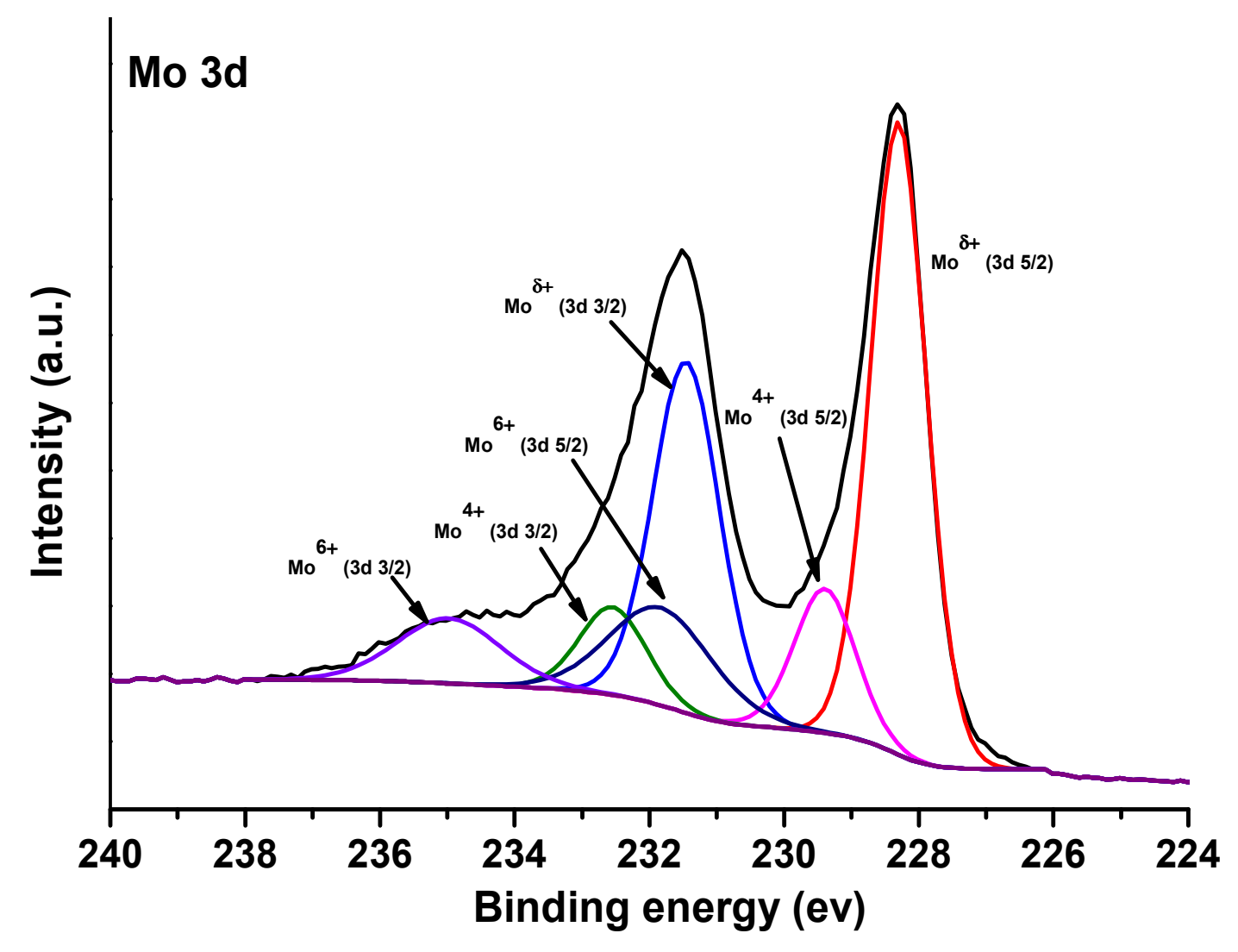

Figure S8. XPS spectrum of Mo $3 \mathrm{~d}$ region of $\mathrm{Mo}_{2} \mathrm{~N}$. 


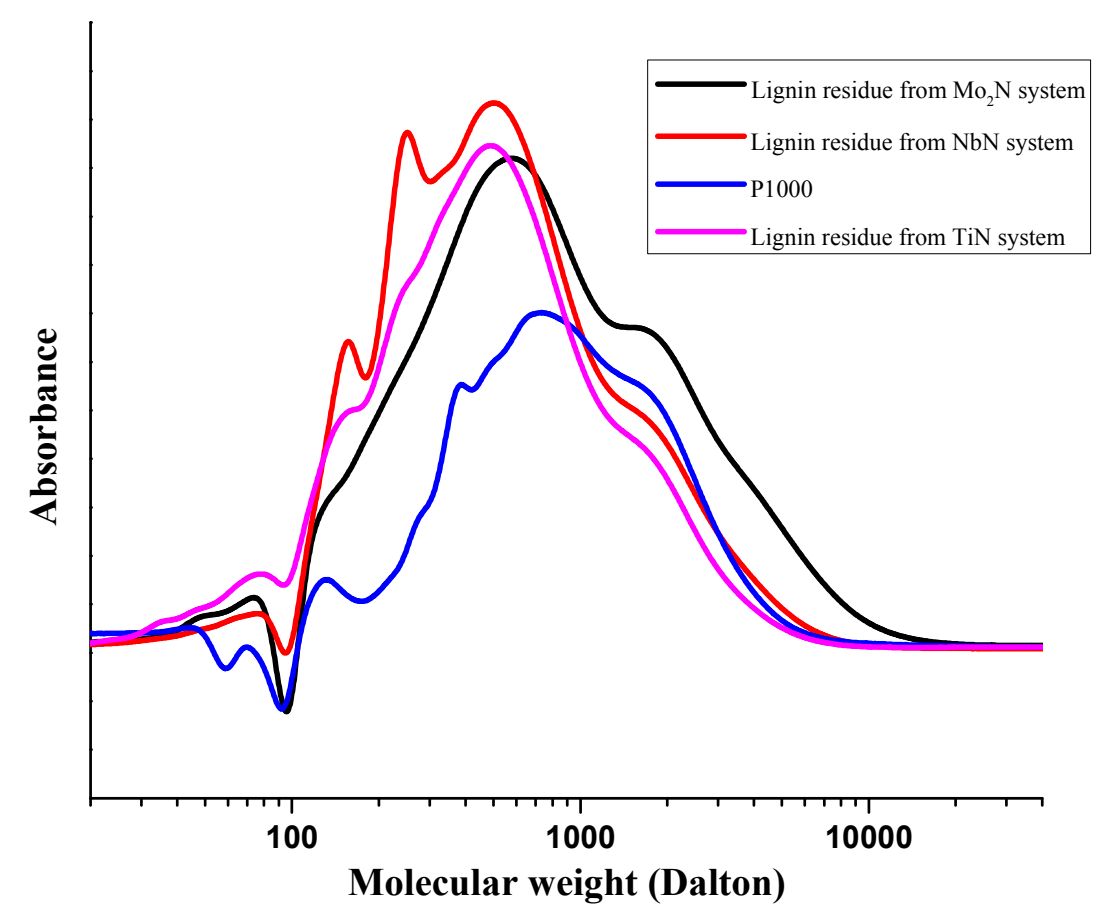

Figure S9. GPC of lignin residues from different catalytic systems compared with native fractioned lignin. 

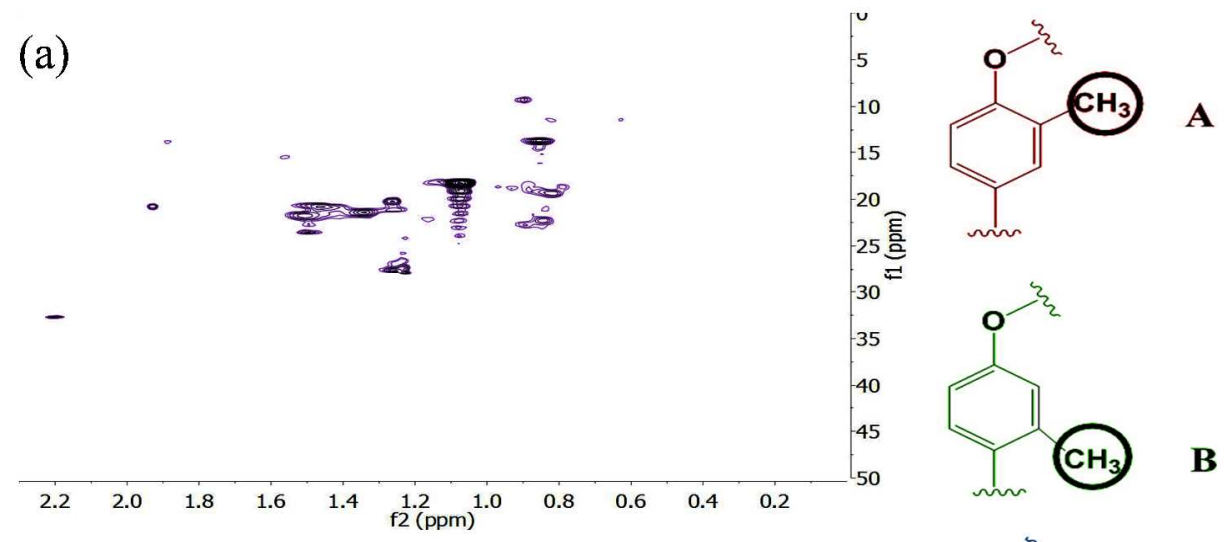

(b)
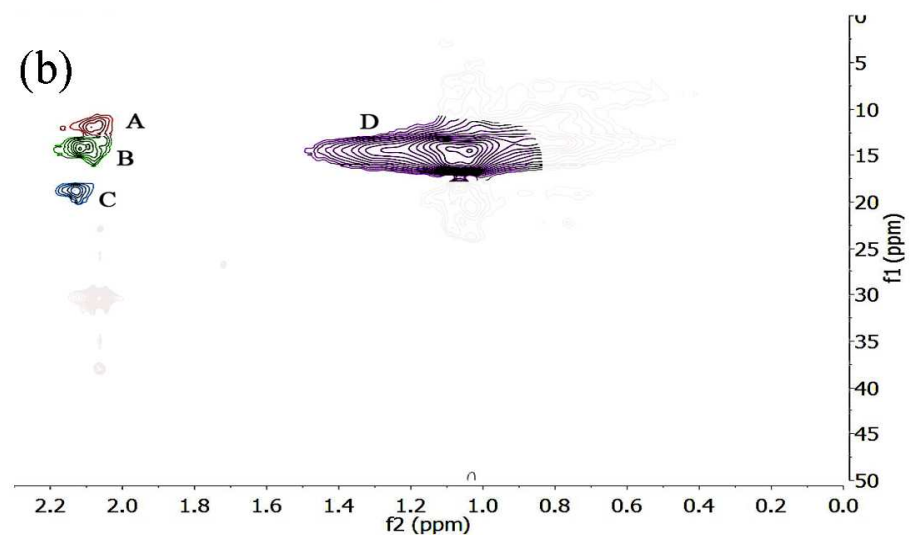

$\overbrace{\mathrm{CH}_{3}}^{0^{-3}}$

$\mathbf{C}$
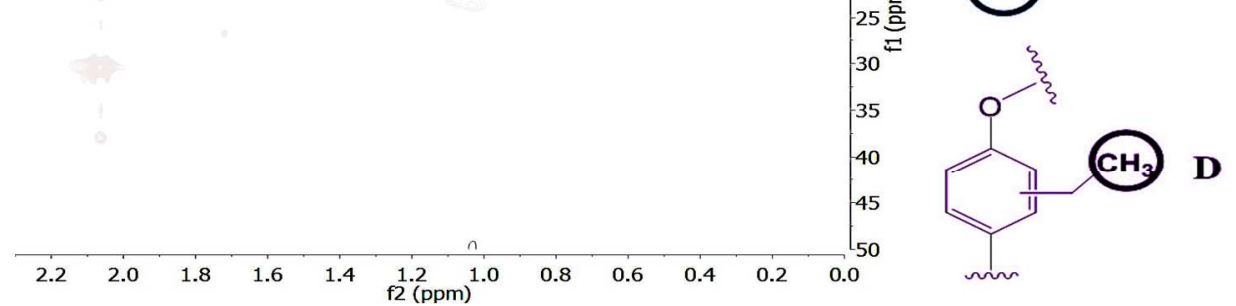

Figure S10. (a) Aliphatic region of HSQC of parent lignin, (b) Aliphatic region of HSQC of lignin residue recovered from entry 8 (Table 1 ) experiment. 


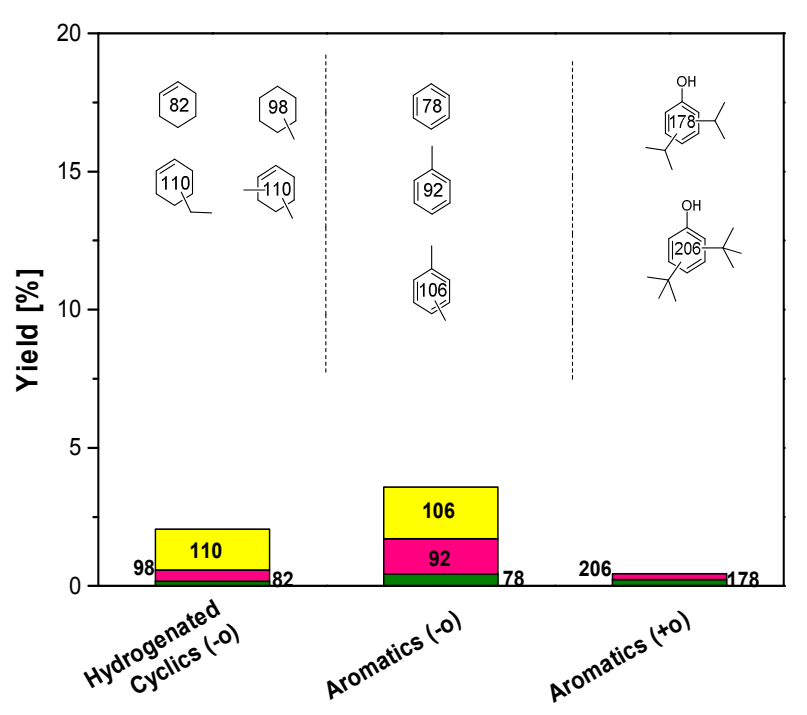

$\mathrm{Mo}_{2} \mathrm{~N}$ system

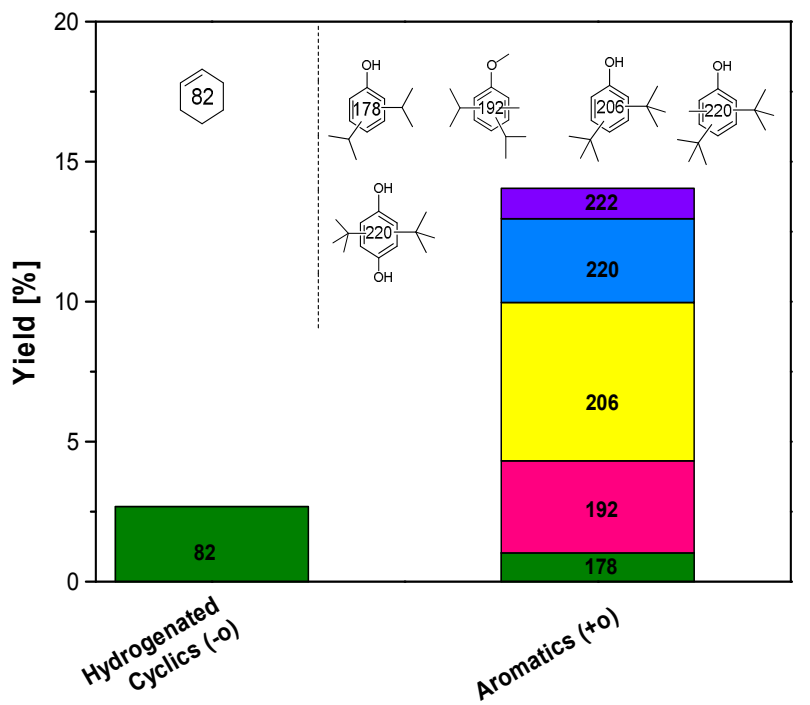

NbN system

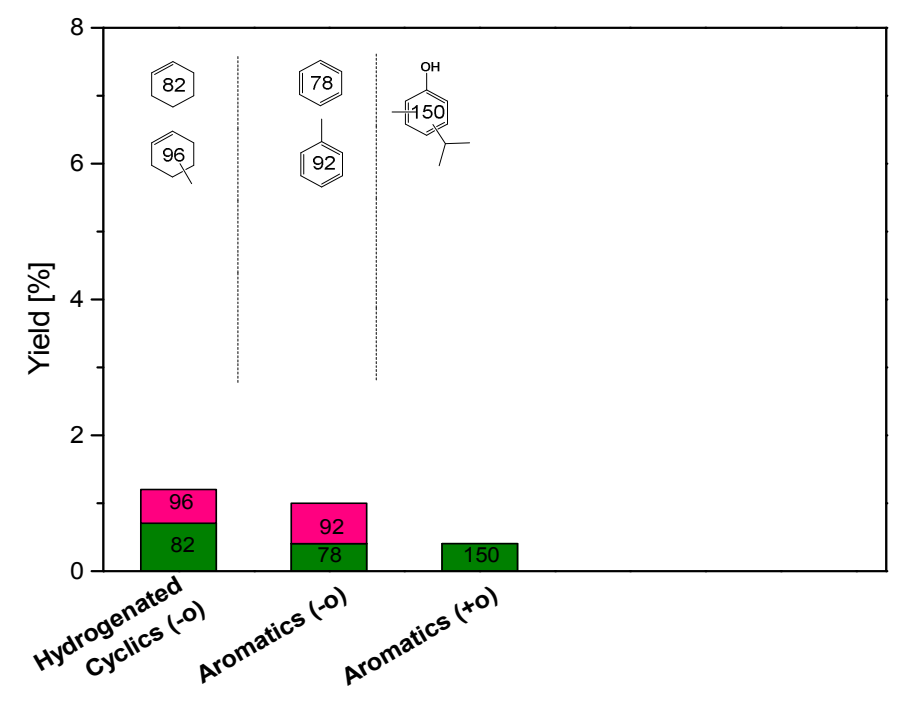

$\mathrm{W}_{2} \mathrm{~N}$ system

Figure S11. Products distribution in the monomers obtained from P1000 depolymerisation catalysed by $\mathrm{Mo}_{2} \mathrm{~N}, \mathrm{NbN}$ and $\mathrm{W}_{2} \mathrm{~N}$ at $340{ }^{\circ} \mathrm{C}$. 

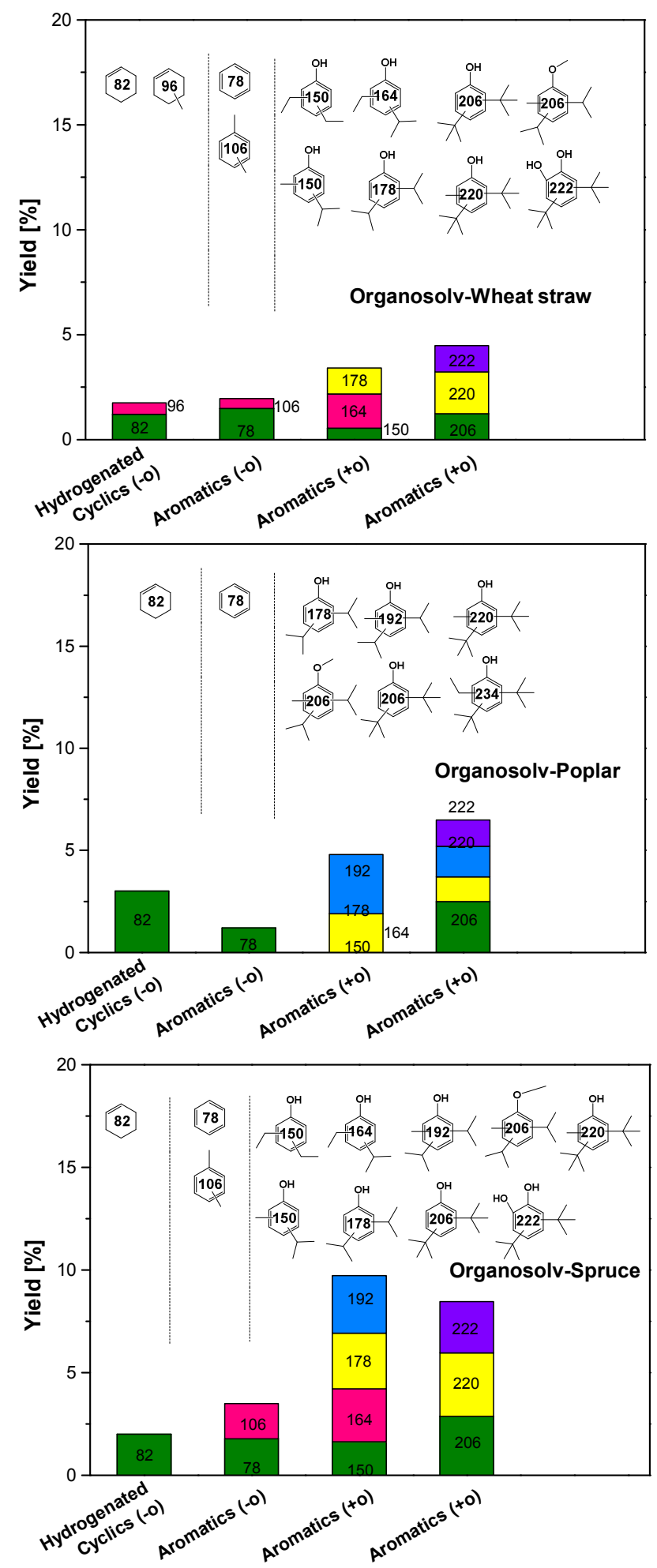

Figure S12. Products distribution in the monomers obtained from three types of organosolv lignin depolymerisation catalysed by $\mathrm{TiN}$ at $340{ }^{\circ} \mathrm{C}$. 
Rebuttal to the referee comments

\section{Referee 1:}

In this work, the authors tested a number of transition metal (Ti, Mo, Nb, W) nitride catalysts for lignin depolymerisation. The distribution and monomeric yields of aromatics depended on the transition metal species. TiN was proved to be the best catalyst with $19 w t \%$ yields. The model compound of guaiacol was used to elucidate the reaction mechanism of lignin depolymerisation over TiN catalyst. The content is interesting but a major revision is suggested. Key points (may be too much for a communication):

We thank the reviewer for the detailed analysis - we believe that a communication is in place here as the result that TiN works without metal added well in this kind of chemistry is important. Yet, we wish to be complete and therefore added all relevant information to reproduce and value these results in the SI. The issues raised by the reviewer are discussed below.

In Figure S7, give the JCPDS or PDF number of Mo2N phase and reconfirm the belonging of the (202) plane. It is not consistent with literature.

The reviewer is right, the figure and the indications were updated.

In Figure S8, reconfirm the peak at $231.8 \mathrm{eV}$ represent Mo4+ (3d 3/2), also some inconsistency.

Yes, we agree that this is an inconsistency. The peak at $231.9 \mathrm{eV}$ is due to $\mathrm{Mo}^{6+}\left(3 \mathrm{~d}_{5 / 2}\right)$, the one at $232.6 \mathrm{eV}$ is of course belonging to Mo4+ $\left(3 \mathrm{~d}_{3 / 2}\right)$. We have corrected Figure S8 accordingly.

In Figure S9, after calibration, the retention times should be replaced by molecular weight.

Based on the calibration of the GPC, we replaced retention time by molecular weight.

Figure $\mathrm{S} 13$ is not mentioned in the text.

We have removed this reference. 
In Table 1, since the alkyl groups of aromatic products originated from the ethanol solvent, monomer yield was not suitable for the calculation of mass balance.

We agree that the mass balance might lead to some confusion in this particular case and have therefore deleted this column from Table 1.

Where are the methyl and isopropyl groups of aromatic products from? If they are from ethanol solvent, please give the evidence and detailed reaction pathways. In addition, the lignin in this text contains a large quantity of methoxyl groups, and where does these groups go, in the state of methanol, methane or other forms.

We thank the reviewer for pointing out these issues. In an earlier work, we have shown that methanol and formaldehyde originating from demethoxylation of lignin can react with ethanol to produce various kinds of alcohols and esters (Ref. 18). These can give then rise to $\mathrm{C} 3, \mathrm{C} 4$ and higher alcohols. Ethanol itself can condense into butanol. We have observed higher amounts of i-propanol and t-butanol with TiN as compared with other catalysts. The extensive alkylation by these products is explained by the high activity of TiN in the alkylation of aromatics with alcohols (reference 17). We also emphasized in the revised manuscript that the amount of gases produced in the TiN catalyzed lignin conversion is much smaller than when a metal catalyst is used (Ref. 18). This is an additional benefit of the TiN catalyst.

Except for alkyl groups, the system during reaction should produce various kinds of radicals such as methyl, methoxyl and ethoxyl, why can only alkylation reaction from alkyl groups suppress the repolymerisation. Please give the reasonable explanation.

This is a very good question. As a reasonable explanation, we can state that, when the reaction is carried out without catalyst, the results are very poor in the sense that lots of condensed product is formed with little aromatics. The char yield is higher than $40 \mathrm{wt} \%$. Accordingly, we believe that alkylation is an important element in explaining the improved yields. We have mentioned this issue in the revised text.

In Figure 4, the results involving guaiacol highlighted the performance of demethoxylation and alkylation, but the hydrogenation of benzene ring and the formation of dihydric phenols in the lignin depolymerisation cannot be explained by the conversion of guaiacol, and the product distribution is quite different, for example no 
tert-butyl group in Figure 4. Please give the reason. The conversion of guaiacol is quite high, and carbon balance based on mole numbers needs to be provided.

We thank the reviewer for his eye for detail. The difference in product distribution evidences that the fragments derived from lignin by its deconstruction are not alike guaiacol - a wider range of structures is obtained with different reactivity. The extent of aromatic ring hydrogenation is limited with TiN and typically cyclohexenes are seen. We argue that in the guaiacol experiments these products are not observed because no BTX was obtained from guaiacol under the given conditions. One explanation for this difference could be that phenolic $\mathrm{OH}$ groups tend to coordinate by the hydroxyl moiety to the catalytic surface rather than the aromatic $\pi$-system. In any case, the extent of aromatic ring hydrogenation when starting from lignin is also relatively small. As to the difference in $t$-butylation in model and lignin experiments, we speculate that the higher amount of methanol (derived from demethoxylation of guaiacol) resulted in more prominent (iso)propylation than in the case of lignin as a reactant. We estimated the guaiacol conversion for the experiment in Fig. 4 ( $X>98 \%$ ), but did not give detailed product yields as we only carried out this experiment using GC-MS (no quantification by FID carried out).

Why the performance of Mo2N catalyst here is different from that of reference $10 ?$

Of course, we can only speculate on this issue. Yet, our Mo2N catalyst was prepared by the urea glass method, while the catalyst in Ref. 10 is prepared in a different way and is also supported on alumina. In such case, various issues might be mentioned such as the particle size effect, the $\mathrm{Mo}_{2} \mathrm{~N}$ phase as well as the role of the alumina support. 


\section{Referee: 2}

Comments to the Author

Hensen and co-workers report on a new set of transition metal nitride catalysts for the depolymerisation of both lignin as well as a lignin model compound, namely guaiacol. It was found that in particular TiN is a very effective catalyst, which is able to convert in supercritical ethanol at 300 degrees $C$ lignin (and its constituents) in alkylated aromatics.

The paper reports novel data, is well-written and is both insightful as broad in scope (screening of materials, as well as brief mechanistic study on TiN). Based on these findings I believe the work is worthwhile to be published in Chemical Communications.

We thank the reviewer for the positive remarks and useful comments.

Some small suggestions for improvements:

Figure 1 is not really needed and can be moved to the supporting information;

We agree and moved this figure to the SI.

I would compare and discuss the behavior of metal nitrides relative to metal sulphides and metal carbides, especially the Mo and $W$ versions, both families have also been studied for guaiacol conversion in the context of lignin valorization. This would broaden the scope of the article.

Unfortunately, we did not carry out an extensive study of the performance of Mo- and W-nitrides in guaiacol conversion as this was not the focus of our paper. Yet, we believe it is a worthwhile point - our revised manuscript contains a short descriptive of the difference in product yields and reactivity of the nitrides in which we also mention carbides and sulphides. 


\title{
COMMUNICATION
}

Transition metal ( $\mathrm{Ti}, \mathrm{Mo}, \mathrm{Nb}, \mathrm{W})$ nitride catalysts for lignin

Cite this: DOI: $10.1039 / \times 0 \times x 00000 x$

\section{depolymerisation}

\author{
Long Chen, TamasTamás I. KoranyiKorányi, Emiel J.M. Hensen*
}

Received 00th January 2015

Accepted 00th January 2015

DOI: 10.1039/x0xx00000x

www.rsc.org

Metal nitrides are promising catalysts for depolymerisation of lignin in supercritical ethanol; cheap and abundant titanium nitride affords an aromatic monomer yield of $19 \mathrm{wt} \%$ from soda lignin. The reaction mechanism is discussed on the basis of the products and a guaiacol model compound study.

The inevitable decrease in the supply of cheap petroleum resources, the increased energy demand in emerging economies and environmental concerns about climate change are main motivators for developing sustainable processes for production of fuels and chemicals. Lignocellulosic biomass is the only sustainable source of organic carbon. ${ }^{1}$ Interest in lignin upgrading has increased because the amount of waste lignin in biorefineries is expected to be substantial. $^{2}$ Lignin constitutes $15-30 \mathrm{wt} \%$ of lignocellulosic biomass with an energy content of up to $40 \%{ }^{3}$ Lignin is also the only renewable source of aromatics. ${ }^{4}$ Compared with upgrading of (hemi)cellulose, lignin valorisation is technically challenging because of its low reactivity and heterogeneity in terms of the chemical bonds between its constituents. Another aspect is the high reactivity of the low-molecular-weight fragments from lignin, which are usually rapidly repolymerizedrecondensed, forming larger andan even more refractory productsproduct than the parent lignin. ${ }^{2(a), 5}$ To date, various strategies for lignin valorisation have emerged, such as cracking, reduction and oxidation. ${ }^{4 \mathrm{c}, 6}$ Oil yields are relatively low, and char and tar are eften observed ascommon side-products. Usually, catalysts contain precious group metals $\overline{-}_{-}$(PGMs), which limits the viability of such processes for large-scale production of fuels and chemicals.

Transition metal nitrides have shown promise as active catalysts for hydrodesulfurization and hydrodeoxygenation reactions of fossil and biomass feedstock. ${ }^{7}$ Compared with metal sulphides commonly used in such operations, metal nitrides are appealing, because they have properties that place them between high performance ceramics and Pt group metals PMs. $^{8}$ They are resistant against corrosion, which is advantageous in large-scale lignin conversion processes that typically require harsh conditions. ${ }^{9}$ There are relatively few examples of the use of metal nitrides in lignin upgrading. Ma et al. ${ }^{10}$ demonstrated catalytic conversion of Kraft lignin in supercritical ethanol over $\mathrm{Mo}_{2} \mathrm{~N} / \mathrm{Al}_{2} \mathrm{O}_{3}$ catalyst without external hydrogen. There areOnly few reperts about works have dealt with the use of TiN in this context. ${ }^{11}$ The use of $\mathrm{Ni}$ in combination with TiN forshows promise in the hydrogenolysis of aryl ethers has been explored. ${ }^{1 \text { la }}$

Partial depolymerization of Kraft lignin with relatively low aromatic monomer yield $(<5 \mathrm{wt} \%)$ was achieved with a Ni/TiN combination, in which $\mathrm{Ni}$ was partially doped into $\mathrm{TiN} .{ }^{1 \mathrm{~b}}$ Herein, we show that TiN itself is a promising catalyst for depolymerisation of soda and organosolv ligninslignin. In this work, we demonstrate that good monomer yield (19 wt \%) can be obtained using TiN in supercritical ethanol. The excellent performance of $\mathrm{TiN}$ in comparison to $\mathrm{TiO}_{2}$ and other metal nitrides is emphasized.

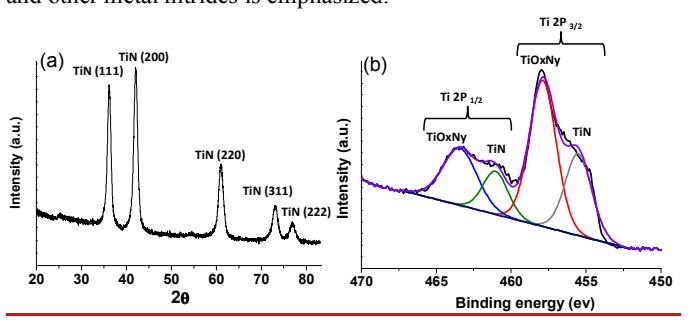

Figure 1. (a) XRD pattern and (b) Ti $2 p$ region of the X-ray photoelectron spectrum of TiN prepared by the urea glass method.

TiN nanoparticles were synthesized by the urea glass method (see the experimental section in ESI + ) followed by passivation in diluted oxygen. ${ }^{12}$ The XRD pattern in Figure 1(a) S1a shows that pure TiN (JCPDS 87-0633) was obtained by this high-temperature approach. From XRD, we estimated an average size of $11 \mathrm{~nm}$ for the TiN crystals, consistent with TEM results (Figure S2, ESI $\dagger$ ). The BET surface area of TiN was about $107 \mathrm{~m}^{2} / \mathrm{g}$ (Figure S3, ESI $\dagger$ ), which was much higher than that of a commercial TiN sample- $\left(3 \mathrm{~m}^{2} / \mathrm{g}\right.$, TEM image is shown in Figure S4). The Ti $2 p$ envelope of the XPS spectrum of TiN, which is shown in Figure $1(b)$, contains evidence for the presence of $\mathrm{S} 1 \mathrm{~b}$, evidences that $\mathrm{TiN}$ and Ti-oxynitride are present. $^{13}$ The oxynitride surface species originate from the passivation step.

We first screened various Ti-based catalysts for the depolymerisation of soda lignin (GreenValue P1000, obtained by $\mathrm{NaOH}$ pulping of wheat straw) in ethanol at $300{ }^{\circ} \mathrm{C}$ (Table 1, entries 1-4). We employed an extensive work-up procedure to allow accurate quantification of the amount of monomers, THF-soluble lignin residue (with molecular weights close to or lower than the starting lignin), THF-insoluble lignin residue (high molecular weight 
products attached to the catalyst) and char (see ESI+). Among these catalysts, the home-made TiN nanoparticles prepared by us-(Table 1, entry 4) demonstratedshowed the highest activity in terms of

Table 1. Yields of menemers, lignin residue, char and mass balance after reaction catalysed by different catalysts

TiN made by the urea glass method is much more active in lignin depolymerization than the commercial TiN sample. The higher activity of the in-house preparedurea glass TiN sample is likely due to the much smaller particle size ${ }^{14}$ yet also the deeper oxidation of the surface of the commercial TiN sample may have to do with this. In any case, $\mathrm{TiO}_{2}$ itself is a poor catalyst. ${ }^{1 \mathrm{~b}}$ Besides promising monomer yield, the urea glass TiN sample only produces $4 \mathrm{wt} \%$ monomer yield. The yield of monomers in TiN (urea glass) system was $(12 \mathrm{wt} \% \%)$.

char, much lower than the other catalysts and also than the blank reaction experiment. We speculate that the-lignin will beis thermally fragmented in supercritical ethanol, consistent with the notion that most of the $\beta-O-4$ ether linkages are cleaved between $200-400{ }^{\circ} \mathrm{C} .{ }^{15}$ Thus, higher The relatively high reaction temperatures may betemperature employed here is expected to facilitate the cleavage of less reactive linkages present in the lignin.

\begin{tabular}{|c|c|c|c|c|c|c|}
\hline Entry & Catalyst & $\begin{array}{c}\text { Temp. } \\
\left({ }^{\circ} \mathrm{C}\right)\end{array}$ & Lignin & $\begin{array}{c}\text { Monomer yield } \\
(\mathbf{w t} \%)\end{array}$ & $\begin{array}{c}\text { THF-soluble } \\
\text { (wt\%) }\end{array}$ & $\begin{array}{l}\text { Char } \\
(\text { wt\%) }\end{array}$ \\
\hline 1 & Blank & 300 & $\mathrm{P} 1000$ & 1 & 30 & 44 \\
\hline 2 & $\mathrm{TiO}_{2}(\mathrm{P} 25)$ & 300 & P1000 & 6 & 42 & 26 \\
\hline 3 & TiN (Sigma) & 300 & P1000 & 1 & 39 & 22 \\
\hline 4 & TiN (urea glass) & 300 & P1000 & 12 & 61 & 4 \\
\hline 5 & Blank & 340 & P1000 & 1 & 36 & 51 \\
\hline 6 & $\mathrm{TiO}_{2}(\mathrm{P} 25)$ & 340 & P1000 & 9 & 41 & 35 \\
\hline 7 & $\operatorname{TiN}^{2}$ (Sigma) & 340 & P1000 & 2 & 39 & 39 \\
\hline 8 & TiN (urea glass) & 340 & P1000 & 19 & 51 & 11 \\
\hline 9 & $\mathrm{NbN}$ (urea glass) & 340 & $\mathrm{P} 1000$ & 17 & 61 & 12 \\
\hline 10 & $\mathrm{Mo}_{2} \mathrm{~N}$ (urea glass) & 340 & $\mathrm{P} 1000$ & 7 & 59 & 15 \\
\hline 11 & $\mathrm{~W}_{2} \mathrm{~N}$ (urea glass) & 340 & P1000 & 3 & 65 & 34 \\
\hline 12 & TiN (urea glass) & 340 & Organosolv - straw & 16 & 50 & 13 \\
\hline 13 & TiN (urea glass) & 340 & Organosolv - poplar & 15 & 47 & 15 \\
\hline 14 & $\mathrm{TiN}$ (urea glass) & 340 & Organosolv - spruce & 21 & 45 & 11 \\
\hline
\end{tabular}

To verify this, we depolymerized lignin at the higher temperature of monomers could be identified, we authenticated 2,6-di-t-butylphenol $340{ }^{\circ} \mathrm{C}$ (Table 1, entries 5-8). For all catalysts, we obtained higher as one of the products. Compared with the work of Huang et al. ${ }^{18}$ monomer yields at this), which led to increased employing a mixed Cu-Mg-Al-oxide catalyst, more $t$-butylation was temperature monomer yield for TiN $(19 \mathrm{wt} \%)$. At this stage, we also observed, which is due to the partial conversion of ethanol to $t$ included a fewseveral other metal nitrides $\left(\mathrm{NbN}, \mathrm{Mo}_{2} \mathrm{~N}\right.$ and $\left.\mathrm{W}_{2} \mathrm{~N}\right)$ butanol with TiN. $i$-Propylation of aromatics derives from $i$ prepared by the same urea glass method (see basic characterization propanol, which is observed as the product of condensation of in Figures S5-S8 in ESI*) for comparison. The monomer yield was methanol, obtained by demethoxylation of lignin, and ethanol. The 19 for the $\mathrm{TiN}$ namepricles. The performance of $\mathrm{NbN}$ was alkylation degree of the few aromatic monomers obtained with $\mathrm{TiO}_{2}$ comparable in terms of monomer and char yield, while Mo- and W- and the commercial TiN sample was much lower.

nitrides gaveproduced less monomers and more char. The lowest performance of $\mathrm{W}_{2} \mathrm{~N}$ is likely due to the low dispersion.

In attempting to understand the mechanism of the complex depolymerisation process catalysed by $\mathrm{TiN}$, we investigated the main reaction products in more detail. The monomer product distribution for the TiN catalyst at $300{ }^{\circ} \mathrm{C}$ and $340{ }^{\circ} \mathrm{C}$ is shown in | Figure 31 . The products are categorized in three classes, namely hydrogenated cyclics, oxygen-free aromatics and oxygen-containing aromatics. The presence of hydrogenated cyclic products can be | attributed to the slightly metallic character of TiN, which facilitates hydrogen transfer reactions of the solvent. ${ }^{16}$ The yield of hydrogenated cyclics (mostly cyclohexenes) is relatively low, yet increases with temperature $\left(1.5 w t^{\circ} \%\right.$ and $2.7 w t \%$ at $300^{\circ} \mathrm{C}$ and 340 ${ }^{\circ} \mathrm{C}$, respectively).: Strikingly, a significant amount of alkylated aromatic products werewas obtained in these lignin depolymerisation reactions. The extent of alkylation was higher at $340{ }^{\circ} \mathrm{C}$, suggesting a prominent rolepointing to the importance of alkylation in obtaining highgood monomer yield. It is indeed known that $\mathrm{TiN}$ is an active catalyst for aromatics alkylation reactions of aromatics-with alcohols. ${ }^{17}$ The relation between alkylation and-good monomer yield in lignin depolymerisation is in keeping with results of Huang et al., ${ }^{18}$ who found that alkylation of reactive phenolic | intermediates suppresses their repolymerizationrecondensation into heavy products. Although not all alkyl side-chains in the aromatic 

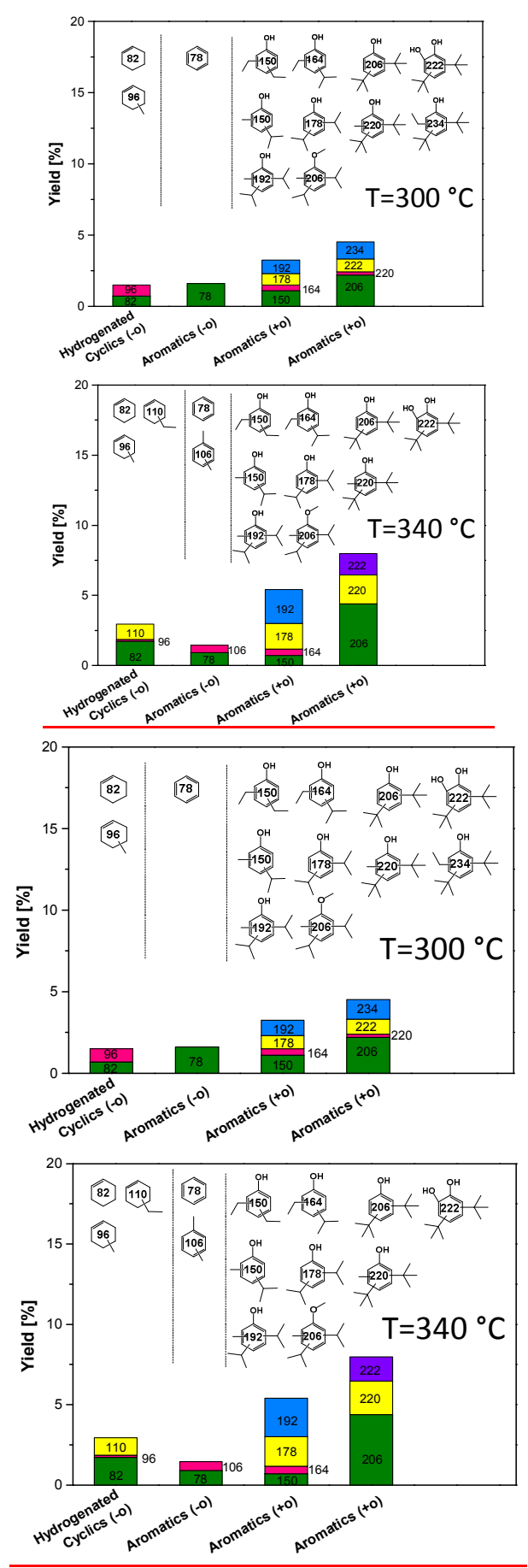

Figure 31. Distribution of monomeric products from lignin depolymerisation using TiN at $300{ }^{\circ} \mathrm{C}$ (top) and $340^{\circ} \mathrm{C}$ (bottom), entries 4 and 8 in Table 1 .

In order to better understand the changes occurring during lignin depolymerisation, we also investigated the THF-soluble lignin residue in more detail. GPC analysis (Figure S9, ESI $\dagger$ ) demonstrates that the molecular weight of the lignin residue is lower than that of the starting lignin. Comparison of ${ }^{13} \mathrm{C}-{ }^{1} \mathrm{H}$ HSQC NMR spectra (Figure S10, ESI $\dagger$ ) of the parent lignin and this residue showed the appearance of cross-peaks of alkyl groups bound to aromatic rings. This indicates that TiN catalyses alkylation during depolymerisation of lignin in ethanol. ${ }^{18}$-Thus, alkylation by alcohols catalysed by TiN protects aromatic monomers from recondensingbeing recondensed, which explains the high monomer and lower char yield. This conclusion is further underpinned by the low monomer and high char yield in the absence of catalysts that can catalyse alkylation. It is also important to stress that only very few gaseous hydrocarbon products were obtained in the experiments with TiN, which constrasts the more prominent gas make by ethanol reforming in the presence of metallic catalysts. ${ }^{18}$

Detailed product distributions for lignin depolymerisation using $\mathrm{NbN}, \mathrm{Mo}_{2} \mathrm{~N}$ and $\mathrm{W}_{2} \mathrm{~N}$ catalysts are given in the ESI $\dagger$ (Figure S11). From this, it can be concluded that $\mathrm{NbN}$ catalyses similar chemistry as TiN.With, which likely is due to the Lewis acidity of the exposed metal centers. NbN is less effective than TiN in oxygen removal, leading to high yield of oxygenated aromatics. On the other hand, $\mathrm{Mo}_{2} \mathrm{~N}$ and $\mathrm{W}_{2} \mathrm{~N}$ as catalysts,produce much more oxygen-free aromatics are obtained, as expected givenconsistent with the notion that these nitrides, just like their known carbidic and sulphidic counterparts, are good eatalytic performance in catalysts for hydrodeoxygenation of oxygenated aromatics. ${ }^{19}$ The lower monomer yields for obtained with $\mathrm{Mo}_{2} \mathrm{~N}$ and $\mathrm{W}_{2} \mathrm{~N}$ correlateappear to be correlated with their lower alkylation activity. Relatively speaking, these catalysts produce more aromatics than TiN and $\mathrm{NbN}$.

To assess the utility of eurthe TiN catalyst in lignin depolymerisation, we determined theevaluated its performance in depolymerising three different types of organosolv ligninslignin originating from wheat straw and poplar and spruce wood (Table 1, entries 9-11). In all of these cases, the depolymerisation process proceeded efficiently, resulting in promisingcomparable monomer yield with relatively lowsmall amounts of char. The lower monomer yield obtained from wheat straw is likely due to the higher fraction of C-C type intralinkages in this type of lignin, which relates to its relatively high $\mathrm{H}$ unit content. The monomer products distributions ef-distribution obtained from these three organosolv ligninsdifferent lignin sources were similar with the one of P1000 lignin (Figure $\mathrm{S} 12, \mathrm{ESI}+$ ). These results demonstrateunderpin the high efficiency and versatility of high surface area TiN prepared by the urea glass method for lignin depolymerisation.

To gain further insight into the mechanism of lignin depolymerisation in the TiN-ethanol system, we evaluateddetermined by GC-MS the products obtained in the conversion of guaiacol as a model compound. The chromatogram in Figure 4 shows The conversion of guaiacol is nearly complete and the range of monomeric products ebtained, highlightingin the chromatogram in Figure highlights the high rates of demethoxylation and alkylation. The amount of oligomerization is limited, showing the effectiveness of alkylation. ${ }^{20}$ Compared with lignin experiments, less $t$-butylation is observed, which is likely due to the larger amount of $i$-propanol formed due to condensation of methanol (from guaiacol demethoxylation) with ethanol. Another difference is that no ring hydrogenation is observed in the aromatic oxygenates obtained from guaiacol. This result is in keeping with the result that only aromatic rings of completely deoxygenated compounds are 
hydrogenated in the lignin conversion experiments. A tentative explanation is that the coordination of oxygenated aromatics is via the phenolic $\mathrm{OH}$ groups, while compounds like benzene will coordinate via their $\pi$-system to the surface.

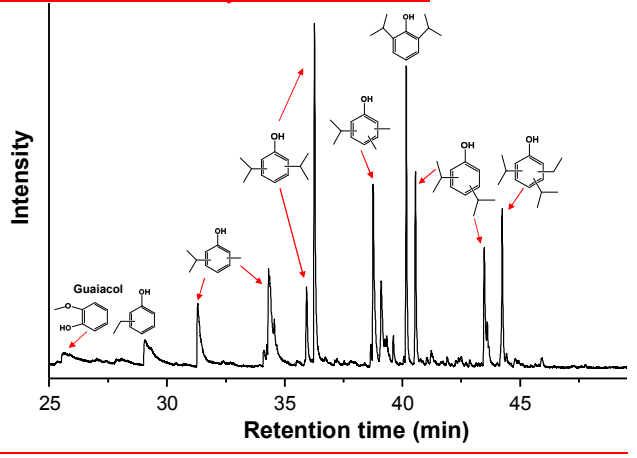

Fioure 4. GC-MS chromatooram of ouraiacol conversion in supercritical ethanol at $300^{\circ} \mathrm{C}$ catalysed by urea glass prepared TiN.

In summary, transition metal nitrides and especially nanoparticulate $\mathrm{TiN}$ are promising for the partial depolymerisation of lignin. In supereritical ethanel, Good aromatic monomer yields at relatively low char formation rate arecan be obtained- in supercritical ethanol. Key to the promising monomer yield is aromatic ring alkylation. While $\mathrm{NbN}$ catalyses similar ehemistry, while less alkylating $\mathrm{Mo}_{2} \mathrm{Nchemistry \textrm {Mo } _ { 2 }} \mathrm{N}$ and $\mathrm{W}_{2} \mathrm{~N}$ show much lower performance in terms of monomer yield. The alkylation degree of these monomers is lower, yet more deoxygenated and preference for deoxygenation.hydrogenated products are observed. TiN can be used to partially depolymerise soda and organosolv lignin with promising monomer yieldsyield.

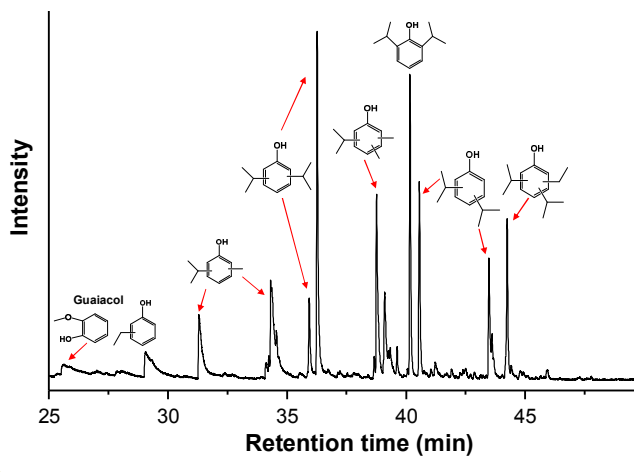

Figure 2. GC-MS chromatogram of guaiacol conversion in supercritical ethanol at $300^{\circ} \mathrm{C}$ catalysed by urea glass prepared TiN.

\section{Acknowledgements}

| The authors gratefully acknowledge the support of CatchBio, the Smart Mix Program of the Netherlands Ministry of Economic Affairs and the Netherlands Ministry of Education, Culture and Science.

\section{Notes and references}

Laboratory of Inorganic Materials Chemistry, Schuit Institute of Catalysis, Department of Chemical Engineering and Chemistry, Eindhoven University of Technology, P.O. Box 513, 5600 MB Eindhoven, The Netherlands. E-mail: e.j.m.hensen@tue.nl

† Electronic Supplementary Information (ESI $\dagger)$ available: Experiments and catalyst characterization details, products distributions, lignin residue characterisation results. See DOI:10.1039/b000000x/

1. a) G. W. Huber, S. Iborra, A. Corma, Chem. Rev. 2006, 106, 4044-4098; b) A. J. Ragauskas, C. K. Williams, B. H. Davison, G. Britovsek, J. Cairney, C. A. Eckert, W. J Frederick Jr., J. P. Hallett, D. J. Leak, C. L. Liotta, J. R. Mielenz, R. Murphy, R. Templer, T. Tschaplinski, Science 2006, 27, 484-489.

2. a) A. J. Ragauskas, G. T. Beckham, M. J. Biddy, R. Chandra, F. Chen, M. F. Davis, B. H. Davison, R. A. Dixon, P. Gilna, M. Keller, P. Langan, A. K. Naskar, J. N. Saddler, T. J. Tschaplinski, G. A. Tuskan, C. E. Wyman, Science 2014, 344, 1246843; b) J. G. Lingera, D. R. Vardona, M. T. Guarnieri, E. M. Karp, G. B. Hunsinger, M. Ann Franden, C. W. Johnson, G. Chupkad, T. J. Strathmannc, P. T. Pienkosa, G. T. Beckham, Proc. Natl. Acad. Sci. 2014, 111, 12013-12018.

3. a) M. Stöcker, Angew. Chem. Int. Ed. 2008, 47, 9200-9211; b) J. R. Regalbuto, Science 2009, 325, 822-824.

4. a) C. O. Tuck, E. Pérez, I. T. Horváth, R. A. Sheldon, M. Poliakoff, Science 2012, 337, 695-699; b) S. R. Collinson, W. Thielemans, Coord. Chem. Rev. 2010, 254, 1854-1870; c) J. Zakzeski, P. C. A. Bruijnincx, A. L. Jongerius, B. M. Weckhuysen, Chem. Rev. 2010, 110, 3552-3599.

5. J. Y. He, C. Zhao, D. H. Mei, J. A. Lercher, J. Catal. 2014, 309, 280290.

6. a) Y. Zheng, D. Y. Chen, X. F. Zhu, J. Anal. Appl. Pyrol. 2013, 104, 514520; b) J. G. Zhang, J. Teo, X. Chen, H. Asakura, T. Tanaka, K. Teramura, N. Yan, ACS Catal. 2014, 4, 1574-1583; c) A. R. Gonçalves, P. Benar, Bioresource Technol. 2001, 79, 103-111.

7. a) I. T. Ghampson, C. Sepúlved, R. Garcia, L. R. Radovi, J. L. García Fierro, W. J. De Sisto, N. Escalona, Appl. Catal. A: Gen. 2012, 439, 111124; b) B. Diaz, S. J. Sawhill, D. H. Bale, R. Main, D. C. Phillips, S. Korlann, R. Self, M. E. Bussell, Catal. Today, 2003, 86,191-206.

8. a) R. B. Levy, M. Boudart, Science 1973, 181, 547-549; b) H. H. Hwu, J. G. Chen, Chem. Rev. 2005, 105, 185-212.

9. M. Marlo, V. Milman, Phys. Rev. B 2000, 62, 2899-2907.

10. X. Ma, R. Ma, W. Hao, M. Chen, F. Yan, K. Cui, Y. Tian, Y. Li, ACS Catal. 2015, 5, 4803-4813.

11. a) V. Molinari, C. Giordano, M. Antonietti, D. Esposito, J. Am. Chem. Soc. 2014, 136, 1758-1761; b) V. Molinari, G. Clavel, M. Graglia, M. Antonietti, D. Esposito, ACS Catal. 2016, 6, 1663-1670.

12. C. Giordano, C. Erpen, W. T. Yao, B. Milke, M. Antonietti, Chem. Mater., 2009, 21, 5136-5144

13. a) B. Yoo, K. J. Kim, Y. H. Kim, K. Kim, M. J. Ko, W. M. Kim, N. G. Park, J. Mater. Chem. 2011, 21, 3077-3084; b) X. Y. Liu, Y. H. Zhang, T. Wu, J. G. Huang, Chem. Commun. 2012, 48, 9992-9994.

14. a) S. Kaskel, K. Schlichte, G. Chaplais and M. Khanna, J . Mater. Chem. 2003, 13, 1496-1499; b) R. A. Janes, M. Aldissi and R. B. Kaner, Chem. Mater. 2003, 15, 4431-4435.

15. a) Q. Song, F. Wang, J. Y. Cai, Y. H. Wang, J. J. Zhang, W. Q. Yu, J. Xu, Energy Environ. Sci. 2013, 6, 994-1007; b) P. Ferrini, R. Rinaldi, Angew. Chem. Int. Ed. 2014, 53, 8634-8639. c) E. Dorrestijn, L. J. J. Laarhoven, I. W. C. E. Arends, P. Mulder, J. Anal. Appl. Pyrolysis 2000, 54, 153-192.

16. S. Kaskel, K. Schlichte, T. Kratzke, J. Mol. Catal. A: Chem. 2004, 208 , 291-298.

17. a) W. T. Yao, P. Makowski, C. Giordano, F. Goettmann, Chem. Eur. J. 2009, 15, 11999-12004; b) A. Fischer, P. Makowski, J. Müller, M. Antonietti, A. Thomas, F. Goettmann, ChemSusChem 2008, 1, 444-449.

18. a) X. M. Huang, T. I. Korányi, M. D. Boot, E. J. M. Hensen, ChemSusChem, 2014, 7, 2276-2288; b) X. M. Huang, T. I. Korányi, M. D. Boot, E. J. M. Hensen, Green Chem. 2015, 17, 4941-4950; c) X. M. Huang, C. Atay, T. I. Korányi, M. D. Boot, E. J. M. Hensen, ACS Catal. 2015, 5, 7359-7370.

19. C. Sepúlveda, K. Leiva, R. García, L. R. Radovic, I. T. Ghampson, W. J. De Sisto, J. L. García Fierro, N. Escalon, Catal. Today, 2011, 172, 232239.

20. a) A. Brandt, J. Grasvik, J. P. Hallett, T. Welton, Green Chem., 2013, 15,
Formatted: Font: (Default) Myriad Pro, 8 pt, Character scale: $108 \%$ 
550-583; b) A. Brandt, L. Chen, B. E. van Dongen, T. Welton, J. P. Hallett, Green Chem., 2015,17, 5019-5034; c) W. Boerjan, J. Ralph, M. Baucher, Annu. Rev. Plant Biol., 2003, 54, 519-546. 